\title{
Retrieval of tropospheric CO column from hyperspectral infrared sounders - application to four years of Aqua/AIRS and MetOp-A/IASI
}

\author{
T. Thonat ${ }^{1}$, C. Crevoisier ${ }^{1}$, N. A. Scott ${ }^{1}$, A. Chédin ${ }^{1}$, T. Schuck ${ }^{2}$, R. Armante ${ }^{1}$, and L. Crépeau ${ }^{1}$ \\ ${ }^{1}$ Laboratoire de Météorologie Dynamique (LMD), UMR8539, CNRS - IPSL, Ecole Polytechnique, Palaiseau, France \\ ${ }^{2}$ Atmospheric Chemistry Division, Max Planck Institute for Chemistry, Mainz, Germany
}

Correspondence to: T. Thonat (thibaud.thonat@lmd.polytechnique.fr)

Received: 10 May 2012 - Published in Atmos. Meas. Tech. Discuss.: 31 May 2012

Revised: 13 September 2012 - Accepted: 18 September 2012 - Published: 17 October 2012

\begin{abstract}
Four years of tropospheric integrated content of $\mathrm{CO}$ were retrieved from infrared hyperspectral observations of AIRS onboard Aqua and IASI onboard MetOp-A, for the period July 2007-June 2011. The retrieval method is based on a double differential approach that relies on the difference between brightness temperatures observed by the sounder and BT simulated by the Automatised Atmospheric Absorption Atlas (4A) radiative transfer model on colocated ECMWF reanalyses, for several couples of channels located in the $4.67 \mu \mathrm{m} \mathrm{CO}$ band. AIRS and IASI give access to similar integrated contents of $\mathrm{CO}$ with a maximum sensitivity near $450 \mathrm{hPa}$ and a half-height width of the weighting function between 200 and $750 \mathrm{hPa}$ depending on the thermal contrast (i.e., the difference between the surface temperature and the temperature of the first pressure level). However, differences in their spectral and radiometric characteristics yield differences in the retrieval characteristics with AIRS selected couples of channels being more sensitive to surface characteristics. Moreover, IASI covers the whole CO absorption band, with a 3 times better spectral resolution, giving access to channels presenting a 3 times higher signal to noise ratio. This results in a better precision and lower standard deviation of the IASI retrievals. Conservatively, comparisons with CARIBIC aircraft measurements yield an averaged relative difference of $3.4 \%$ for IASI and $4.9 \%$ for AIRS. On average, AIRS and IASI retrievals are in very good agreement, showing the same seasonality, seasonal amplitudes, interannual variability and spatial distribution. The analysis of the monthly evolution of $\mathrm{CO}$ particularly highlights the expected strong influence of biomass burning on the evolution of $\mathrm{CO}$
\end{abstract}

in several tropical regions. In particular, a sharp increase in CO in 2010 in the southern tropics, especially over South America and South Africa, is observed, and is shown to be related to El Niño and to the Atlantic Multidecadal Oscillation.

\section{Introduction}

Tropospheric carbon monoxide (CO) is produced by the combustion of fossil fuel, biomass burning and the oxidation of biogenic hydrocarbons and methane. At northern midlatitudes, the main source is fossil fuel combustion, while in the tropics the three other sources prevail. Its removal by $\mathrm{OH}$ makes $\mathrm{CO}$ an important gas by indirectly influencing greenhouse gases which reacts with $\mathrm{OH}$, such as $\mathrm{CH}_{4}$ and halocarbons, and by playing a role in the production of $\mathrm{CO}_{2}$ and $\mathrm{O}_{3}$, which is an air pollutant. $\mathrm{CO}$ has a lifetime ranging from 10 days in the tropics in summer to more than a year over the poles in winter. Thanks to its relatively long atmospheric lifetime, $\mathrm{CO}$ also serves as a tracer of long-range transport of pollution, and plays a key role in the understanding of the biomass burning issue. For all these reasons, an accurate monitoring of $\mathrm{CO}$ is essential to better understand the spatiotemporal variability of CO sources and sinks (Holloway et al., 2000; Duncan et al., 2007).

Ground-based accurate measurements of $\mathrm{CO}$ are available (e.g., from the World Data Center for Greenhouse Gases; WMO, 2009), but they are quite sparse, and mainly concentrated in Europe and North America. Aircraft measurements 
also provide data on $\mathrm{CO}$ (e.g., the MOZAIC, CARIBIC and CONTRAIL programmes; Nedelec et al., 2003; Brenninkmeijer et al., 2007; Machida et al., 2008), but are limited in time and space. As a consequence, $\mathrm{CO}$ observations from space have been used in recent years to get a global coverage. The first space borne instrument to monitor $\mathrm{CO}$ was the Measurement Atmospheric Pollution from Space (MAPS), which flew onboard the Space Shuttle for a few days in 1981, 1984 and 1994 (Reichle Jr. et al., 1999). It was followed by the Interferometric Monitor for Greenhouse gases instrument (IMG) that operated between October 1996 and June 1997 (Clerbaux et al., 1999). Over the past decade, several nadir viewing instruments have been measuring tropospheric CO with a greater spatial and temporal coverage, including the Measurements of Pollution in the Troposphere instrument (MOPITT, launched in March 2000; Deeter et al., 2003, 2009), the Atmospheric Infrared Sounder (AIRS, launched in May 2002; McMillan et al., 2005), the Scanning Imaging Absorption Spectrometer for Atmospheric Chartography (SCIAMACHY, launched in March 2002; Buchwitz et al., 2004; Frankenberg et al., 2005; de Laat et al., 2006) and the Tropospheric Emission Spectrometer (TES, launched in July 2004; Rinsland et al., 2006). With the exception of SCIAMACHY, which measures the scattered, reflected and transmitted near-infrared solar radiation, giving access to the full CO column, these instruments are thermal infrared sounders, thus, mostly sensitive to $\mathrm{CO}$ in the midtroposphere. These instruments have stressed the great value of infrared observation of $\mathrm{CO}$ from space, by providing a better constraint on top-down flux inversions (e.g., Kopacz et al., 2010; Fortems-Cheiney et al., 2011), and by giving valuable information on specific signals such as fire emissions (Edwards et al., 2004; Yurganov et al., 2008), pollution events (Turquety et al., 2008) or the impact of El Niño (Rinsland et al., 2008).

With its 8461 channels covering most of the infrared spectrum at a very high resolution, the Infrared Sounding Interferometer (IASI) was launched in October 2006 onboard the European MetOp-A platform, and is operational since July 2007. Like the AIRS instrument, it has been designed to provide water vapour and temperature soundings for operational meteorology, as well as to observe simultaneously the most important trace gases (e.g., $\mathrm{H}_{2} \mathrm{O}, \mathrm{CO}_{2}, \mathrm{~N}_{2} \mathrm{O}, \mathrm{CO}$, $\mathrm{CH}_{4}, \mathrm{O}_{3}, \mathrm{SO}_{2}, \mathrm{H}_{2} \mathrm{~S}, \mathrm{NH}_{3}, \mathrm{HNO}_{3}$, VOCs; Hilton et al., 2012). Some studies have already highlighted the suitability of IASI to measure CO from space (Turquety et al., 2009; George et al., 2009; Illingworth et al., 2011). These studies presented retrievals of $\mathrm{CO}$ based on optimal estimation techniques. Here, we use an alternative approach for the retrieval of a tropospheric integrated content of $\mathrm{CO}$, that relies on differences between simulated and observed radiances from selected couples of AIRS and IASI channels, chosen to enhance the $\mathrm{CO}$ signature in the radiances, and that allows us to study the characteristics of the retrieved $\mathrm{CO}$ stemming from the spectral and radiometric characteristics of the sounders.
Our study focuses on the tropics, where strong fire $\mathrm{CO}$ emissions are located, because the detection mask for clouds and aerosols that was used at the time of this study was only available for this region. Section 2 describes the data and modelling tools used in the retrieval process. Section 3 presents the study of the sensitivities of AIRS and IASI channels to $\mathrm{CO}$ and other atmospheric and surface variables. Section 4 describes the method used to retrieve CO. Section 5 presents the results, comparisons with CARIBIC measurements and analysis of the retrieved $\mathrm{CO}$ in terms of geographic distribution and monthly evolution in light of fire activity and climate indexes. Section 6 concludes this study.

\section{Data and models}

\subsection{AIRS}

The Atmospheric Infrared Sounder (AIRS) is a polarorbiting nadir-viewing instrument. It was launched onboard the Aqua satellite in May 2002, and is operational since September 2002. With its 2378 channels, its spectral domain ranges from $650 \mathrm{~cm}^{-1}$ to $2665 \mathrm{~cm}^{-1}(15.4 \mu \mathrm{m}$ and $3.8 \mu \mathrm{m})$, with a resolving power $(\lambda / \Delta \lambda)$ of 1200 (i.e., a spectral resolution ranging from $0.5 \mathrm{~cm}^{-1}$ to $2 \mathrm{~cm}^{-1}$ ). This domain is divided into three spectral bands, from 650 to $1135 \mathrm{~cm}^{-1}$, from 1215 to $1615 \mathrm{~cm}^{-1}$ and from 2180 to $2665 \mathrm{~cm}^{-1}$. AIRS cross-track scanning is $1650 \mathrm{~km}$ and covers $70 \%$ of the earth every day. The instantaneous field of view (IFOV) is sampled by $3 \times 3$ circular pixels whose ground resolution is $13 \mathrm{~km}$ at nadir. In this study, use is made of the Version 5 Level $1 \mathrm{~b}$ data (available at: http://mirador.gsfc.nasa.gov/). Also flying onboard Aqua, the Advanced Microwave Sounding Unit (AMSU) observations are used in this study for cloud detection.

\subsection{IASI}

The Infrared Atmospheric Sounding Interferometer (IASI) is a high resolution Fourier Transform Spectrometer based on a Michelson Interferometer coupled to an integrated imaging system that measures infrared radiation emitted from the Earth. Developed by the Center National d'Etudes Spatiales (CNES) in collaboration with the European Organisation for the Exploitation of Meteorological Satellites (EUMETSAT), IASI was launched in October 2006 onboard the polarorbiting Meteorological Operational Platform (MetOp-A), and is operational since July 2007. IASI provides $8461 \mathrm{spec-}$ tral samples, ranging from $645 \mathrm{~cm}^{-1}$ to $2760 \mathrm{~cm}^{-1}(15.5 \mu \mathrm{m}$ and $3.6 \mu \mathrm{m})$, with a spectral sampling of $0.25 \mathrm{~cm}^{-1}$, and a spectral resolution of $0.5 \mathrm{~cm}^{-1}$ after apodisation ("Level $1 \mathrm{c}$ " spectra). IASI is an across track scanning system, whose swath width is of $2200 \mathrm{~km}$, allowing global coverage twice a day. The IFOV is sampled by $2 \times 2$ circular pixels whose ground resolution is $12 \mathrm{~km}$ at nadir. In this study, use is made of the Level 1c data (available at the Ether Center 
for Atmospheric Chemistry Products and Services website: http://ether.ipsl.jussieu.fr/, via EUMETCAST). The observations from the AMSU instruments flying onboard MetOp-A are also used for cloud detection.

\subsection{CARIBIC}

CARIBIC (Civil Aircraft for the Regular Investigation of the Atmosphere Based on an Instrument Container) is a longterm scientific project conducting measurements of trace gases and aerosol particles in the upper troposphere and lowermost stratosphere (Brenninkmeijer et al., 2007). A comprehensive package of 18 individual instruments housed inside a $1.5 \mathrm{t}$ air freight container is regularly loaded into a Lufthansa A340-600 passenger aircraft equipped with a specially designed air inlet. Measurement flights are performed over 2-4 consecutive days once per month during regular flights. Routine deployment of the current system started in May 2005 and is ongoing. The instrumentation includes an in situ analyser for continuous measurements of $\mathrm{CO}$ based on a commercial ultraviolet fluorescence instrument (Aero-Laser, AL 5002) which has been modified for use onboard aircraft (Scharffe et al., 2012). The instrument achieves a precision of 1-2 ppbv, the time resolution is $1 \mathrm{~s}$. Calibration is in-flight every $25 \mathrm{~min}$. Most measurements take place at cruise altitudes around 9-12 km, and data collected during ascent and descent were not used in this study.

\subsection{The 4A fast line-by-line radiative transfer model}

The radiative transfer simulations used in this study are performed by the 4A (Automatised Atmospheric Absorption Atlas) fast and accurate line-by-line radiative transfer model (Scott and Chédin, 1981; http://ara.abct.lmd.polytechnique. $\mathrm{fr} /) .4 \mathrm{~A}$ is developed and maintained at the Laboratoire de Météorologie Dynamique. It has been made operational (OP) in cooperation with the French company Noveltis (see http://www.noveltis.net/4AOP/ for a description of 4AOP). 4A allows fast computation of the transmittance of a discrete atmosphere along the vertical at a very high spectral resolution $\left(5 \times 10^{-4} \mathrm{~cm}^{-1}\right.$ for this study) as well as the Jacobians (Chéruy et al., 1995) (with respect to temperature, mixing ratios and surface temperature and emissivity) for a user-defined observation level. It relies on comprehensive atlases of monochromatic optical thicknesses for up to 43 atmospheric molecular species. The atlases were created by using the line-by-line and layer-by-layer model STRANSAC (Scott, 1974) in its latest version with upto-date spectroscopy from the GEISA (Gestion et Etudes des Informations Spectroscopiques Atmosphériques, Management and Study of Spectroscopic Information) spectral line data catalogue (Jacquinet-Husson et al., 2011). The 4AOP also includes up-to-date continua of $\mathrm{N}_{2}, \mathrm{O}_{2}$ and $\mathrm{H}_{2} \mathrm{O}$. It is the reference forward radiative transfer model for the
CNES/EUMETSAT IASI Level $1 \mathrm{Cal} / \mathrm{Val}$ activities and operational processing.

\subsection{TIGR}

The selection of AIRS and IASI channels presented in Sect. 4.1 is based on the TIGR (Thermodynamical Initial Guess Retrieval) atmospheric and radiative database (Chédin et al., 1985; Chevallier et al., 1998) (available at: http:// ara.abct.lmd.polytechnique.fr/index.php?page=tigr). It comprises 2311 representative atmospheric situations selected by statistical method from 80000 radiosonde reports. Each situation is described by its profiles of temperature, water vapour and ozone, a constant profile of $\mathrm{CO}$, and constant profiles along the vertical of $\mathrm{CO}_{2}(372 \mathrm{ppmv}), \mathrm{N}_{2} \mathrm{O}$ (324 ppbv) and $\mathrm{CH}_{4}$ (1800 ppbv). From each atmospheric situation, 4A is used to compute the corresponding clear sky brightness temperatures, transmittances and Jacobians for the 2378 AIRS channels, the 8461 IASI channels and for all scan angles.

For all TIGR situations, the noise due to the instrument is computed using the following equation:

$\mathrm{NE} \Delta T(\mathrm{BT}(v))=\mathrm{NE} \Delta T\left(T_{\mathrm{ref}}(v)\right) \frac{\frac{\partial B}{\partial T}\left(v, T_{\mathrm{ref}}\right)}{\frac{\partial B}{\partial T}(v, \mathrm{BT}(v))}$

where NE $\Delta T$ is the equivalent noise temperature taken at the brightness temperature $\mathrm{BT}$, of the channel frequency $v$, and $B$ is the radiance. For IASI, the reference noise corresponding to the reference temperature $T_{\text {ref }}$ of $280 \mathrm{~K}$ is taken from the in-flight noise measurement (E. Péquignot, CNES, personal communication, 2009); for AIRS the reference noise at $T_{\text {ref }}$ of $250 \mathrm{~K}$ was provided to us by the AIRS science team.

\section{Study of infrared channels sensitivities}

\subsection{Sensitivities of AIRS and IASI channels to atmospheric and surface perturbations}

The $4.67 \mu \mathrm{m} \mathrm{CO}$ absorption band is located from about $2080 \mathrm{~cm}^{-1}$ to about $2200 \mathrm{~cm}^{-1}$. Here we focus our analysis on the domain located from $2160 \mathrm{~cm}^{-1}(4.63 \mu \mathrm{m})$ to $2200 \mathrm{~cm}^{-1}(4.55 \mu \mathrm{m})$, where the strongest sensitivities to CO are found. Unlike IASI, AIRS spectral domain does not cover completely the $\mathrm{CO}$ absorption band, since AIRS third spectral band begins at $2181.5 \mathrm{~cm}^{-1}$.

In the $4.67 \mu \mathrm{m}$ region, channels sensitive to $\mathrm{CO}$ are also sensitive to other variables that will be referred to as interferences (Crevoisier et al., 2003): surface temperature $\left(T_{\mathrm{S}}\right)$, surface emissivity $\left(\varepsilon_{\mathrm{s}}\right)$, temperature $(T)$, water vapour $\left(\mathrm{H}_{2} \mathrm{O}\right)$, nitrous oxide $\left(\mathrm{N}_{2} \mathrm{O}\right)$ and ozone $\left(\mathrm{O}_{3}\right)$. For each of the 872 TIGR tropical atmospheric situations, variations of brightness temperature induced by variations of atmospheric and surface variables are computed from the Jacobians: 

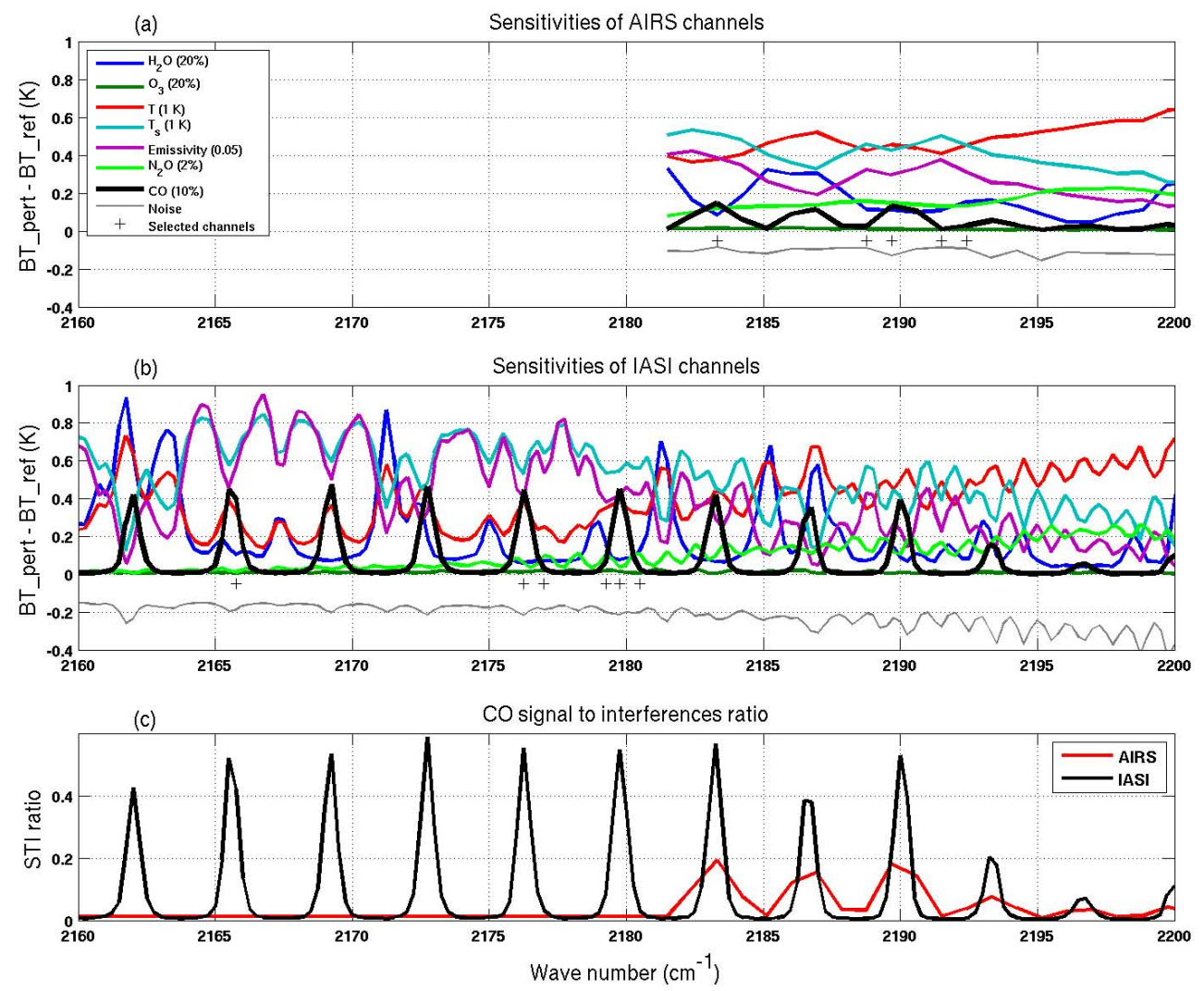

Fig. 1. Sensitivities of (a) AIRS channels and (b) IASI channels to variations of $10 \% \mathrm{CO}$ (black), 0.05 emissivity (magenta), $1 \mathrm{~K}$ surface temperature (cyan), $1 \mathrm{~K}$ temperature (red), $20 \% \mathrm{H}_{2} \mathrm{O}$ (blue), $2 \% \mathrm{~N}_{2} \mathrm{O}$ (pale green) and $20 \% \mathrm{O}_{3}$ (dark green). The grey line is the radiometric noise, multiplied by -1 for clarity. The crosses indicates the position of the selected channels. (c) CO signal to interferences (STI) ratio for AIRS (red) and IASI (black). The sensitivities are computed with 4A and averaged over the 872 TIGR tropical atmospheric situations. AIRS spectral domain does not cover the CO absorption band before $2181.5 \mathrm{~cm}^{-1}$.

$\Delta \mathrm{BT}(T)=\sum_{\mathrm{nl}=1}^{\mathrm{nl}=42} \frac{\partial \mathrm{BT}}{\partial T}(\mathrm{nl}) \times \Delta T(\mathrm{nl})$ for temperature

$\Delta \mathrm{BT}\left(q_{\mathrm{gas}}\right)=\sum_{\mathrm{nl}=1}^{\mathrm{nl}=42} \frac{\partial \mathrm{BT}}{\partial q_{\mathrm{gas}}}(\mathrm{nl}) \times \Delta q_{\mathrm{gaz}}(\mathrm{nl})$ for a gas

where "nl" is the number of pressure layers.

The AIRS and IASI BT variations corresponding to variations of $1 \mathrm{~K}$ of temperature, $1 \mathrm{~K}$ of $T_{\mathrm{S}}, 10 \%$ of $\mathrm{CO}, 20 \%$ of $\mathrm{H}_{2} \mathrm{O}, 2 \%$ of $\mathrm{N}_{2} \mathrm{O}, 20 \%$ of $\mathrm{O}_{3}$ and 0.05 of surface emissivity $\left(\varepsilon_{\mathrm{S}}\right)$, are plotted in Fig. 1a and b.

The difference in spectral resolution between AIRS and IASI is well-seen in Fig. 1: $\sim 1.8 \mathrm{~cm}^{-1}$ for AIRS at $2190 \mathrm{~cm}^{-1}$ and $0.5 \mathrm{~cm}^{-1}$ for IASI. This difference mostly explains the lower sensitivity of AIRS channels to CO. Moreover, AIRS only gives access to the end of the $\mathrm{CO}$ absorption band, which is characterised by lower intensities of the $\mathrm{CO}$ absorption lines. Channels located in the $\mathrm{CO}$ band are also strongly sensitive to $T_{\mathrm{S}}$ and to $\varepsilon_{\mathrm{s}}$. Moreover, as the sensitivity to these two surface parameters gets weaker, the sensitivity to temperature and water vapour gets stronger. The sensitivity to $\mathrm{N}_{2} \mathrm{O}$ is about $0.2 \mathrm{~K}$ for both AIRS and IASI at the end of the band and the sensitivity to $\mathrm{O}_{3}$ is quasi-null. The radiometric noise, computed at the $\mathrm{BT}$ of the TIGR tropical scenes, is weaker for AIRS $(\sim 0.1 \mathrm{~K})$ than for IASI $(\sim 0.2 \mathrm{~K})$.

The comparison between the two instruments in terms of their suitability to measure $\mathrm{CO}$ in the atmosphere may be done by studying the ratio of the $\mathrm{CO}$ signal to the sum of the signals from interference species, including the radiometric noise, hereafter referred to as the STI ratio (for Signal To Interferences ratio) (Crevoisier et al., 2003). Figure 1c shows that the STI ratio for IASI is about three times greater than for AIRS, which means that the weakness of the AIRS CO signal is not compensated by the weakness of the radiometric noise. High values of the STI ratios, for IASI and AIRS, are not only due to particularly low interferences, but also to relatively high sensitivities to $\mathrm{CO}$, as seen in Fig. 1a and b.

\subsection{Jacobians}

The information about the distribution of the sensitivity along the vertical is given by the CO Jacobians. The averaged Jacobians computed with 4A on the TIGR tropical situations 
are plotted in Fig. 2 for the channels presenting the highest sensitivity to CO (see Fig. 1a and b). The shape of the Jacobians are similar for all these channels, with a maximum at about $450 \mathrm{hPa}(\sim 6.5 \mathrm{~km})$, and half the maximum between about $750(\sim 2.5 \mathrm{~km})$ and $200 \mathrm{hPa}(\sim 12 \mathrm{~km})$, with the exception of the channel located at $2162.00 \mathrm{~cm}^{-1}$, less sensitive to $\mathrm{CO}$ near the surface. The AIRS channels are sensitive to $\mathrm{CO}$ in the same part of the atmosphere, with a sensitivity almost three times weaker, in agreement with Fig. 1a and b.

As shown by Deeter et al. (2007) for MOPITT, the vertical sensitivity to $\mathrm{CO}$ varies especially near the surface with the thermal contrast, which is the difference between the surface temperature and the temperature of the first pressure level. Jacobians in Fig. 2a and $b$ have been computed with no thermal contrast. Figure $2 \mathrm{c}$ and $\mathrm{d}$ shows the difference between these Jacobians and those computed with a +10 or $-10 \mathrm{~K}$ thermal contrast. For both instruments, the higher the thermal contrast, the higher the sensitivity to $\mathrm{CO}$ in the lower part of the troposphere, particularly near the surface, with an opposite change of the sensitivity in the upper part of the troposphere. Negative and positive thermal contrasts have symmetric effects.

\section{Retrieval method}

\subsection{Description of the method}

The retrieval method is based on a double differential approach: a difference of channels and a difference between simulated and observed AIRS/IASI BT. The difference of channels is meant to be only sensitive to $\mathrm{CO}$ variations (see below); the corresponding simulations are computed with $4 \mathrm{~A}$, based on the description of the state of the atmosphere given by the ECMWF reanalyses and an a priori CO profile. This double differential approach gives access to a signal only due to $\mathrm{CO}$ in terms of BT. The corresponding $\mathrm{CO}$ mixing ratio (i.e., the difference with the a priori profile) is then computed by taking into account the sensitivity to $\mathrm{CO}$ of the selected channels given by the Jacobians. Overall, the retrieval process can be divided into 3 steps.

First, channels to be used in the retrieval process are selected. This selection is based on the study of the sensitivities of the channels (see Sect. 3). Couples of channels having the same sensitivities to every atmospheric and surface variable but $\mathrm{CO}$ are selected. The difference between the two channels of each couple is, thus, mostly sensitive to $\mathrm{CO}$ and minimises the sensitivity to the interferences. In order to lower the sensitivity to the atmospheric situation, the standard deviation of the differences has also to be minimum over the 872 TIGR tropical situations. Three couples of channels satisfying these criteria have been selected for each instrument. They are given in Tables 1 and 2 together with their characteristics and shown as crosses in Fig. 1. They are very weakly sensitive to $\mathrm{N}_{2} \mathrm{O}$, and almost not to $\mathrm{O}_{3}$. The radiometric noise
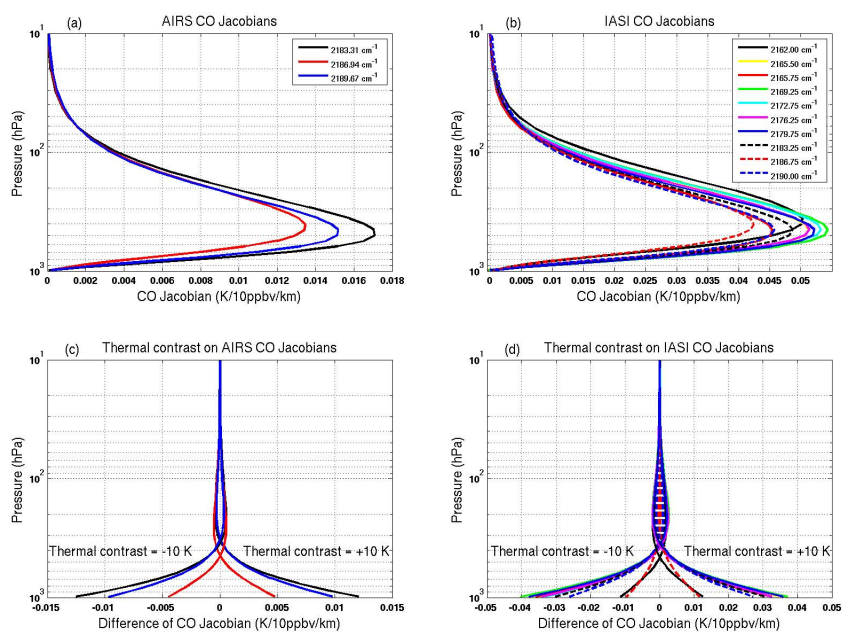

Fig. 2. CO Jacobians $(\mathrm{K} / 10 \mathrm{ppbv} / \mathrm{km})$ corresponding to a variation of $10 \mathrm{ppbv}$ for (a) AIRS and (b) IASI. Effect of thermal contrasts of -10 and $+10 \mathrm{~K}$ on (c) AIRS and (d) IASI CO Jacobians. The Jacobians are computed with 4A and averaged over the 872 TIGR tropical atmospheric situations. The channels represented here are those with the highest sensitivity to CO (see Fig. 1a, b).

for these six channels ranges from 0.09 to $0.13 \mathrm{~K}$ for AIRS, with a standard deviation smaller than $0.03 \mathrm{~K}$; for IASI it ranges from 0.19 to $0.23 \mathrm{~K}$, with a standard deviation below $0.05 \mathrm{~K}$.

Second, ECMWF (European Center for Medium-Range Weather Forecasts) ERA-Interim Reanalyses (http://www. ecmwf.int/; Dee et al., 2011) profiles of $T, \mathrm{H}_{2} \mathrm{O}$ and $\mathrm{O}_{3}$ characterised by a $6 \mathrm{~h}$ time resolution and a $0.75^{\circ} \times 0.75^{\circ}$ space resolution, are colocalised both in time and space to every IASI or AIRS clear-sky FOV and inter/extrapolated on the 4A pressure levels. $T_{\mathrm{S}}$ is estimated directly from one IASI or AIRS channel in order to avoid the lag between the closest reanalyses and the IASI or AIRS passing. Use is made of the IASI BT at $2501.75 \mathrm{~cm}^{-1}$ and the AIRS $\mathrm{BT}$ at $2616.38 \mathrm{~cm}^{-1}$ (E. Péquignot, personal communication, 2012). Table 3 shows the characteristics of these two channels. They are characterised by a very high surface transmission. Based on comparisons between simulations and observations, $T_{\mathrm{S}}$ is equal to IASI/AIRS BT plus $2 \mathrm{~K}$. Surface emissivity is fixed at 0.98 . Based on the spectral variations of $\varepsilon_{\mathrm{S}}$ retrieved from IASI (Capelle et al., 2012), $\varepsilon_{\mathrm{S}}$ does not vary much for the channels used in this study.

Third, $T, \mathrm{H}_{2} \mathrm{O}$ and $\mathrm{O}_{3}$ profiles, $T_{\mathrm{S}}$ and $\varepsilon_{\mathrm{S}}$ are used as inputs to $4 \mathrm{~A}$ to simulate $\mathrm{BT}^{4 \mathrm{~A}}$, for each $\mathrm{FOV}$ and each channel. Then we calculate $\triangle \mathrm{BT}$ as follows:

$$
\begin{aligned}
\Delta \mathrm{BT} & =\left(\mathrm{BT}^{4 \mathrm{~A}}-\mathrm{BT}^{\text {Sounder }}\right)_{\text {channel } 1} \\
& -\left(\mathrm{BT}^{4 \mathrm{~A}}-\mathrm{BT}^{\text {Sounder }}\right)_{\text {channel } 2}
\end{aligned}
$$

where channel 1 is the channel sensitive to $\mathrm{CO}$ and channel 2 the one which is not sensitive to it. $\triangle \mathrm{BT}$ is a signal in $\mathrm{K}$, which is, thus, only due to the excess of $\mathrm{CO}$ in the 
Table 1. Sensitivities of AIRS selected channels, computed with 4A and averaged over the 872 TIGR tropical atmospheric situations.

\begin{tabular}{lrrrrrrrr}
\hline \multirow{2}{*}{ AIRS Channels } & $\begin{array}{r}\text { Wave no. } \\
\left(\mathrm{cm}^{-1}\right)\end{array}$ & $\begin{array}{r}\mathrm{CO} \\
10 \%\end{array}$ & $\begin{array}{r}T_{\mathrm{S}} \\
1 \mathrm{~K}\end{array}$ & $\begin{array}{r}T \\
1 \mathrm{~K}\end{array}$ & $\begin{array}{r}\varepsilon_{\mathrm{S}} \\
0.05\end{array}$ & $\begin{array}{r}\mathrm{H}_{2} \mathrm{O} \\
20 \%\end{array}$ & $\begin{array}{r}\mathrm{N}_{2} \mathrm{O} \\
2 \%\end{array}$ & $\begin{array}{r}\mathrm{O}_{3} \\
20 \%\end{array}$ \\
\hline 1867 & 2183.31 & 0.15 & 0.51 & 0.38 & 0.38 & 0.08 & 0.12 & 0.01 \\
1876 & 2191.45 & 0.01 & 0.50 & 0.41 & 0.37 & 0.11 & 0.13 & 0.01 \\
Difference & & 0.14 & 0.01 & -0.03 & 0.01 & -0.03 & -0.01 & 0.01 \\
Std of the difference & & 0.02 & 0.00 & 0.01 & 0.01 & 0.02 & 0.00 & 0.00 \\
\hline 1874 & 2189.67 & 0.13 & 0.43 & 0.45 & 0.29 & 0.11 & 0.15 & 0.01 \\
1873 & 2188.76 & 0.02 & 0.46 & 0.42 & 0.32 & 0.11 & 0.16 & 0.01 \\
Difference & & 0.11 & -0.03 & 0.03 & -0.03 & 0.00 & -0.01 & 0.00 \\
Std of the difference & & 0.02 & 0.00 & 0.00 & 0.01 & 0.01 & 0.00 & 0.00 \\
\hline 1874 & 2189.67 & 0.13 & 0.43 & 0.45 & 0.29 & 0.11 & 0.15 & 0.01 \\
1877 & 2180.50 & 0.03 & 0.45 & 0.45 & 0.31 & 0.15 & 0.13 & 0.01 \\
Difference & & 0.10 & -0.03 & 0.00 & -0.02 & -0.04 & 0.01 & 0.00 \\
Std of the difference & & 0.02 & 0.01 & 0.01 & 0.01 & 0.03 & 0.00 & 0.00 \\
\hline
\end{tabular}

Table 2. Same as Table 1 for IASI.

\begin{tabular}{lrrrrrrrr}
\hline \multirow{2}{*}{ IASI Channels } & $\begin{array}{r}\text { Wave no. } \\
\left(\mathrm{cm}^{-1}\right)\end{array}$ & $\begin{array}{r}\mathrm{CO} \\
10 \%\end{array}$ & $\begin{array}{r}T_{\mathrm{S}} \\
1 \mathrm{~K}\end{array}$ & $\begin{array}{r}T \\
1 \mathrm{~K}\end{array}$ & $\begin{array}{r}\varepsilon_{\mathrm{S}} \\
0.05\end{array}$ & $\begin{array}{r}\mathrm{H}_{2} \mathrm{O} \\
20 \%\end{array}$ & $\begin{array}{r}\mathrm{N}_{2} \mathrm{O} \\
2 \%\end{array}$ & $\begin{array}{r}\mathrm{O}_{3} \\
20 \%\end{array}$ \\
\hline 6084 & 2165.75 & 0.40 & 0.64 & 0.33 & 0.57 & 0.10 & 0.01 & 0.01 \\
6129 & 2177.00 & 0.03 & 0.64 & 0.25 & 0.54 & 0.07 & 0.10 & 0.02 \\
Difference & & 0.37 & 0.00 & 0.08 & 0.03 & 0.03 & -0.09 & -0.01 \\
Std of the difference & & 0.06 & 0.01 & 0.02 & 0.03 & 0.04 & 0.02 & 0.00 \\
\hline 6126 & 2176.25 & 0.45 & 0.53 & 0.39 & 0.41 & 0.06 & 0.06 & 0.01 \\
6138 & 2179.25 & 0.07 & 0.53 & 0.35 & 0.38 & 0.16 & 0.10 & 0.02 \\
Difference & & 0.38 & 0.00 & 0.04 & 0.03 & -0.10 & -0.04 & -0.01 \\
Std of the difference & & 0.05 & 0.03 & 0.03 & 0.04 & 0.07 & 0.01 & 0.00 \\
\hline 6140 & 2179.75 & 0.45 & 0.55 & 0.40 & 0.41 & 0.07 & 0.04 & 0.01 \\
6143 & 2180.50 & 0.02 & 0.56 & 0.33 & 0.42 & 0.12 & 0.11 & 0.00 \\
Difference & & 0.43 & -0.02 & 0.07 & -0.01 & -0.05 & -0.07 & 0.01 \\
Std of the difference & & 0.07 & 0.02 & 0.02 & 0.03 & 0.04 & 0.01 & 0.00 \\
\hline
\end{tabular}

troposphere compared to the 4A CO reference profile. This excess of $\mathrm{CO}$ is then calculated as follows:

$\Delta q \mathrm{CO}=\frac{\sum_{i=1}^{3} f_{i} \times \Delta \mathrm{BT}_{i}}{\sum_{i=1}^{3} f_{i}^{2}}$

where $f$ is the difference of sensitivity to $\mathrm{CO}$ between the two channels of each couple, computed from the Jacobians (Eq. 3), and $i$ is the number of the couple.

The retrieval method relies on the concurrent use of 4A model based simulations and observations. Therefore, potential systematic radiative biases between simulations and observations must be removed. They are computed for each channel, by day and by night, by averaging, over the tropics $\left(30^{\circ} \mathrm{S}, 30^{\circ} \mathrm{N}\right)$ and over the three first years of the operation of IASI (August 2007-July 2010) and over January-October 2008 for AIRS, the difference between simulations and colocated (in time and space) satellite observations. The simulations are performed using 4A with radiosonde measurements from the ARSA (Analysed
RadioSounding Archive) database (available at: http://ara. lmd.polytechnique.fr/) as inputs. The radiative biases are added to $\mathrm{BT}^{4 \mathrm{~A}}$ in Eq. (4).

\subsection{Clouds and aerosols}

Retrievals are performed in clear-sky only. To detect clouds and aerosols for AIRS data, use is made of several threshold tests based on AIRS and AMSU BT, allowing to discriminate low, medium and high clouds and aerosols (Crevoisier et al., 2003; Pierangelo et al., 2004). A similar method is applied to IASI and AMSU observations. Although efficient, the detection tests might not detect some observations weakly influenced by dust aerosols or by biomass burning aerosols which could particularly impact the retrievals since $\mathrm{CO}$ is emitted mostly by fires in the tropics. In the following, we evaluate the difference between BT in clear-sky conditions and BT with aerosols layers located at different altitudes simulated by $4 \mathrm{~A}$ coupled to the DISORT model (Stamnes et al., 1988), based on the TIGR situations. Following Chédin et al. (2005), we assume that biomass burning aerosol is a 
Table 3. Mean (upper line) and standard deviation (lower line) of the surface transmission $\left(\tau_{\mathrm{s}}\right)$ and sensitivities of AIRS 2333 and IASI 7428 channels used to estimate surface temperature.

\begin{tabular}{lcrrrrrrrrrr}
\hline Channels & $\begin{array}{c}\text { Wave no. } \\
\left(\mathrm{cm}^{-1}\right)\end{array}$ & $\tau_{\mathrm{S}}$ & $\begin{array}{r}\varepsilon_{\mathrm{S}} \\
0.05\end{array}$ & $\begin{array}{r}T_{\mathrm{S}} \\
1 \mathrm{~K}\end{array}$ & $\begin{array}{r}T \\
1 \mathrm{~K}\end{array}$ & $\begin{array}{r}\mathrm{H}_{2} \mathrm{O} \\
20 \%\end{array}$ & $\begin{array}{r}\mathrm{CO}_{2} \\
1 \%\end{array}$ & $\begin{array}{c}\mathrm{O}_{3} \\
20 \%\end{array}$ & $\begin{array}{c}\mathrm{N}_{2} \mathrm{O} \\
2 \%\end{array}$ & $\begin{array}{c}\mathrm{CO} \\
10 \%\end{array}$ & $\begin{array}{c}\mathrm{CH}_{4} \\
10 \%\end{array}$ \\
\hline \multirow{2}{*}{ AIRS } & \multirow{2}{*}{2616.38} & 0.97 & 1.11 & 0.98 & 0.02 & 0.02 & 0.00 & - & - & - & - \\
2333 & & 0.03 & 0.06 & 0.01 & 0.01 & 0.03 & 0.00 & - & - & - & - \\
\hline \multirow{2}{*}{ IASI } & \multirow{2}{*}{2501.75} & 0.90 & 1.01 & 0.92 & 0.07 & 0.01 & 0.00 & - & - & - & - \\
7428 & & 0.01 & 0.08 & 0.01 & 0.01 & 0.02 & 0.00 & - & - & - & - \\
\hline
\end{tabular}

mixture of insoluble aerosol (INSO), water soluble aerosol (WASO) and black carbon aerosol (SOOT). Their optical properties are taken from the Optical Properties of Aerosol and Cloud database (Hess et al., 1998), and the infrared AOD is set to 0.05 at $10 \mu \mathrm{m}$. For the dust aerosol (or mineral transported aerosols, MITR), the AOD is set to 0.2. The results are shown in Tables 4 and 5 .

The AIRS and IASI channels used to retrieve CO show a weak sensitivity to aerosols, especially to biomass burning aerosols. For both instruments, the maximum perturbation induced by smoke aerosols on BT reaches about $0.17 \mathrm{~K}$, which is in the order of the $10 \%$ CO signal for AIRS channels and smaller than the one for IASI channels. For dust aerosols the effect is more important, reaching about $0.80 \mathrm{~K}$ near $7 \mathrm{~km}$ altitude. However, the aerosols effect is cancelled by taking the difference between the two channels of each selected couple, since both channels of each couple have a similar sensitivity to the aerosols. Applying Eq. (5) to these simulated perturbations of BT, the impact of aerosols on the retrieved CO content is assessed. For smoke, it is less than $0.14 \mathrm{ppbv}$ for AIRS, and less than $0.09 \mathrm{ppbv}$ for IASI, which is negligible in both cases. The effect of dust aerosols is more important, but still very weak: less than $0.81 \mathrm{ppbv}$ for AIRS, and less than $0.46 \mathrm{ppbv}$ for IASI.

\subsection{Weighting functions}

Our retrieval method gives access to an integrated content of $\mathrm{CO}$ in the low-to-mid troposphere. In order to derive a theoretical weighting function of $\mathrm{CO}$, which indicates the vertical sensitivity of the retrieval to a variation of $\mathrm{CO}$, the method is first applied to the TIGR database. Both AIRS and IASI weighting functions are plotted in Fig. 3. As expected, they are very close to the CO Jacobians (Fig. 2), with a maximum of sensitivity around $450 \mathrm{hPa}(\sim 6.5 \mathrm{~km})$, and half a maximum between about $200 \mathrm{hPa}(\sim 12 \mathrm{~km})$ and about $750 \mathrm{hPa}$ $(\sim 2.5 \mathrm{~km})$. IASI and AIRS are sensitive to the same part of the troposphere, enabling a direct comparison of the CO column retrieved from both instruments.

The effect of the thermal contrast on the weighting functions is also shown in Fig. 3. The higher the thermal contrast, the higher the sensitivity to $\mathrm{CO}$ near the surface, and the lower the sensitivity in the mid troposphere. Compared to the weighting function with no thermal contrast,

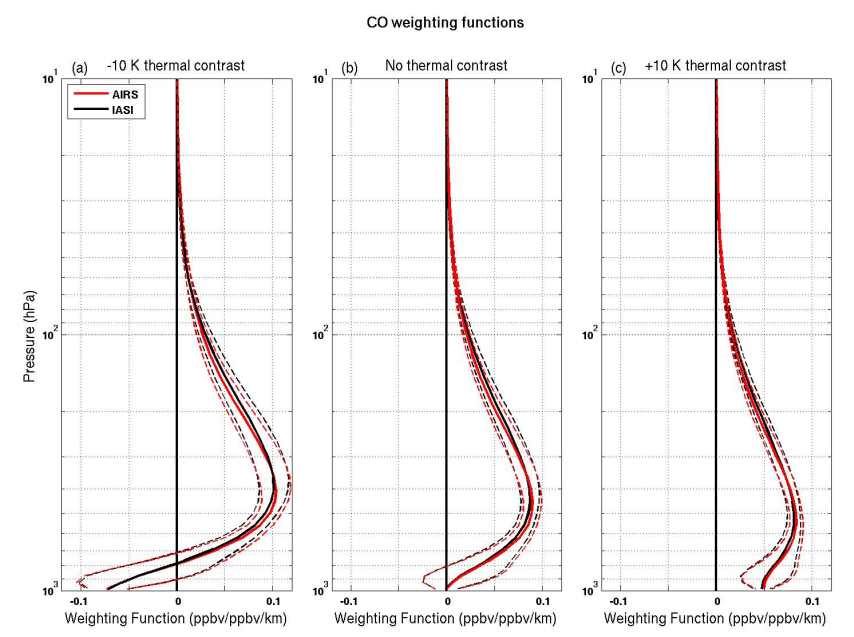

Fig. 3. Mean (solid lines) \pm standard deviation (dashed lines) of the weighting functions of AIRS (red) and IASI (black), with (a) a $-10 \mathrm{~K}$ thermal contrast, (b) a null thermal contrast, and (c) a $+10 \mathrm{~K}$ thermal contrast (right). The weighting functions are computed over the 872 TIGR tropical atmospheric situations.

the maximum of the weighting function is lower by about $50 \mathrm{hPa}(\sim 0.8 \mathrm{~km})$ for the $+10 \mathrm{~K}$ thermal contrast and higher by about $50 \mathrm{hPa}(\sim 0.8 \mathrm{~km})$ for the $-10 \mathrm{~K}$ case. Taking the difference of BT between two channels of a selected couple allows cancelling the effect of $T_{\mathrm{S}}$ on them. However, there is still a dependency on $T_{\mathrm{S}}$ via its effect on the sensitivity to $\mathrm{CO}$ of a given channel.

\section{Results}

The method is now applied to observations made by AIRS and IASI for the period July $2007-J u n e ~ 2011$, over $\left(30^{\circ} \mathrm{S}\right.$, $30^{\circ} \mathrm{N}$ ), over land and over sea, by day and by night.

\subsection{Assessing the precision of the method}

The precision of the retrievals is evaluated by applying random variations to the input variables and then by computing the effects of such variations on the retrieved $\mathrm{CO}$ mixing ratio. For each situation (i.e., for each $0.75^{\circ} \times 0.75^{\circ}$ grid cell), $T_{\mathrm{s}}$, profiles of $T, \mathrm{H}_{2} \mathrm{O}$ and $\mathrm{N}_{2} \mathrm{O}$ are randomly modified using 
Table 4. Difference (in K) between simulated AIRS and IASI BT in clear-sky and BT with biomass burning aerosols, and corresponding perturbation of retrieved $\mathrm{CO}$, for different altitudes, for the channels selected to retrieve $\mathrm{CO}$.

\begin{tabular}{|c|c|c|c|c|c|c|c|c|c|c|c|c|c|}
\hline & \multirow[b]{2}{*}{ Channels } & \multirow[b]{2}{*}{$\begin{array}{r}\text { Wave no. } \\
\left(\mathrm{cm}^{-1}\right)\end{array}$} & \multicolumn{11}{|c|}{ Altitude (km) } \\
\hline & & & 0.25 & 0.75 & 1.24 & 1.72 & 2.33 & 3.11 & 3.90 & 4.66 & 5.39 & 6.08 & 6.74 \\
\hline \multirow{7}{*}{ AIRS } & 1867 & 2183.31 & 0.01 & 0.01 & 0.02 & 0.03 & 0.05 & 0.07 & 0.10 & 0.12 & 0.13 & 0.15 & 0.16 \\
\hline & 1876 & 2191.50 & 0.01 & 0.01 & 0.02 & 0.03 & 0.05 & 0.07 & 0.09 & 0.11 & 0.13 & 0.15 & 0.16 \\
\hline & 1874 & 2189.67 & 0.00 & 0.01 & 0.02 & 0.03 & 0.04 & 0.07 & 0.09 & 0.11 & 0.13 & 0.14 & 0.16 \\
\hline & 1873 & 2188.76 & 0.01 & 0.01 & 0.02 & 0.03 & 0.05 & 0.07 & 0.09 & 0.11 & 0.13 & 0.15 & 0.16 \\
\hline & 1874 & 2189.67 & 0.00 & 0.01 & 0.02 & 0.03 & 0.04 & 0.07 & 0.09 & 0.11 & 0.13 & 0.14 & 0.16 \\
\hline & 1877 & 2180.50 & 0.01 & 0.01 & 0.02 & 0.03 & 0.05 & 0.07 & 0.09 & 0.11 & 0.13 & 0.15 & 0.16 \\
\hline & \multicolumn{2}{|c|}{$\Delta \mathrm{CO}(\mathrm{ppbv})$} & -0.01 & -0.03 & -0.05 & -0.07 & -0.10 & -0.13 & -0.14 & -0.14 & -0.12 & -0.10 & -0.07 \\
\hline \multirow{7}{*}{ IASI } & 6084 & 2165.75 & 0.01 & 0.02 & 0.03 & 0.04 & 0.06 & 0.08 & 0.10 & 0.12 & 0.14 & 0.15 & 0.16 \\
\hline & 6129 & 2177.00 & 0.01 & 0.02 & 0.03 & 0.04 & 0.06 & 0.08 & 0.10 & 0.12 & 0.14 & 0.16 & 0.17 \\
\hline & 6126 & 2176.25 & 0.01 & 0.01 & 0.02 & 0.03 & 0.05 & 0.07 & 0.09 & 0.11 & 0.13 & 0.15 & 0.16 \\
\hline & 6138 & 2179.25 & 0.01 & 0.01 & 0.02 & 0.04 & 0.05 & 0.08 & 0.10 & 0.12 & 0.14 & 0.15 & 0.17 \\
\hline & 6140 & 2179.75 & 0.01 & 0.01 & 0.02 & 0.04 & 0.05 & 0.07 & 0.10 & 0.12 & 0.13 & 0.15 & 0.16 \\
\hline & 6143 & 2180.50 & 0.01 & 0.01 & 0.02 & 0.04 & 0.05 & 0.08 & 0.10 & 0.12 & 0.14 & 0.15 & 0.16 \\
\hline & \multicolumn{2}{|c|}{$\Delta \mathrm{CO}(\mathrm{ppbv})$} & 0.00 & -0.01 & -0.02 & -0.03 & -0.04 & -0.06 & -0.08 & -0.09 & -0.09 & -0.09 & -0.08 \\
\hline
\end{tabular}

Table 5. Same as Table 4 for dust aerosols.

\begin{tabular}{|c|c|c|c|c|c|c|c|c|c|c|c|c|c|}
\hline & \multirow[b]{2}{*}{ Channels } & \multirow[b]{2}{*}{$\begin{array}{r}\text { Wave no. } \\
\left(\mathrm{cm}^{-1}\right)\end{array}$} & \multicolumn{11}{|c|}{ Altitude (km) } \\
\hline & & & 0.25 & 0.75 & 1.24 & 1.72 & 2.33 & 3.11 & 3.90 & 4.66 & 5.39 & 6.08 & 6.74 \\
\hline \multirow{7}{*}{ AIRS } & 1867 & 2183.31 & 0.09 & 0.13 & 0.18 & 0.24 & 0.31 & 0.41 & 0.52 & 0.61 & 0.69 & 0.76 & 0.82 \\
\hline & 1876 & 2191.50 & 0.09 & 0.13 & 0.18 & 0.24 & 0.31 & 0.41 & 0.51 & 0.60 & 0.68 & 0.74 & 0.80 \\
\hline & 1874 & 2189.67 & 0.07 & 0.10 & 0.15 & 0.20 & 0.28 & 0.38 & 0.48 & 0.57 & 0.66 & 0.73 & 0.79 \\
\hline & 1873 & 2188.76 & 0.08 & 0.11 & 0.16 & 0.22 & 0.29 & 0.39 & 0.50 & 0.59 & 0.67 & 0.74 & 0.80 \\
\hline & 1874 & 2189.67 & 0.07 & 0.10 & 0.15 & 0.20 & 0.28 & 0.38 & 0.48 & 0.57 & 0.66 & 0.73 & 0.79 \\
\hline & 1877 & 2180.50 & 0.07 & 0.11 & 0.16 & 0.22 & 0.30 & 0.40 & 0.50 & 0.60 & 0.67 & 0.74 & 0.80 \\
\hline & \multicolumn{2}{|c|}{$\Delta \mathrm{CO}(\mathrm{ppbv})$} & -0.16 & -0.28 & -0.43 & -0.58 & -0.71 & -0.81 & -0.78 & -0.64 & -0.44 & -0.21 & 0.04 \\
\hline \multirow{7}{*}{ IASI } & 6084 & 2165.75 & 0.14 & 0.18 & 0.23 & 0.29 & 0.36 & 0.45 & 0.54 & 0.62 & 0.68 & 0.74 & 0.78 \\
\hline & 6129 & 2177.00 & 0.13 & 0.18 & 0.23 & 0.29 & 0.36 & 0.46 & 0.55 & 0.64 & 0.71 & 0.77 & 0.82 \\
\hline & 6126 & 2176.25 & 0.10 & 0.14 & 0.18 & 0.24 & 0.31 & 0.41 & 0.50 & 0.59 & 0.67 & 0.74 & 0.80 \\
\hline & 6138 & 2179.25 & 0.09 & 0.14 & 0.19 & 0.25 & 0.34 & 0.44 & 0.54 & 0.63 & 0.70 & 0.76 & 0.81 \\
\hline & 6140 & 2179.75 & 0.10 & 0.14 & 0.19 & 0.25 & 0.32 & 0.42 & 0.52 & 0.61 & 0.68 & 0.75 & 0.80 \\
\hline & 6143 & 2180.50 & 0.10 & 0.14 & 0.19 & 0.25 & 0.32 & 0.42 & 0.52 & 0.61 & 0.68 & 0.75 & 0.80 \\
\hline & \multicolumn{2}{|c|}{$\Delta \mathrm{CO}$ (ppbv) } & 0.05 & -0.02 & -0.01 & -0.19 & -0.30 & -0.40 & -0.45 & -0.46 & -0.43 & -0.39 & -0.33 \\
\hline
\end{tabular}

a normal distribution with a 0 mean and standard deviations of $3 \mathrm{~K}, 2 \mathrm{~K}, 10 \%$ and $2 \%$, respectively.

Resulting induced variations of $\mathrm{CO}$ mixing ratios are computed for January and July 2008, for a random selection of $1 \%$ of all situations over southern Africa. For both AIRS and IASI, the differences between the "modified CO" and the "reference CO" are on average less than $0.10 \mathrm{ppbv}$, with standard deviations of about $2.50 \mathrm{ppbv}$. The contribution of each variable to the total standard deviation is summarised in Table 6.

For IASI, the major influence on the $\mathrm{CO}$ retrievals comes from the temperature profile, with standard deviations of 1.64 and 2.00 ppbv for January and July, respectively. The difference of the BT in each couple increases with $T$ (as expected from Table 2). For AIRS, the influence of the temperature is lower than for IASI: the standard deviations are about $1.2 \mathrm{ppbv}$. This is explained by the fact that the variations of AIRS BT for each couple are of opposite signs and, thus, compensate one another (see Table 1). Moreover, for the region studied here, reanalyses are closer to AIRS passing than to IASI.

The results obtained when varying $T_{\mathrm{S}}$ highlights the strength of our differential method. Although the channels sensitivities to $T_{\mathrm{S}}$ are very important, its effect cancels out when making the BT difference: for IASI, the standard deviations are less than $0.9 \mathrm{ppbv}$. For AIRS, the contribution of $T_{\mathrm{s}}$ 
Table 6. Mean (upper line) and standard deviation (lower line) of variations of AIRS and IASI CO induced by random variations of $T_{\mathrm{S}}(3 \mathrm{~K}), T(2 \mathrm{~K}), \mathrm{H}_{2} \mathrm{O}(10 \%)$ and $\mathrm{N}_{2} \mathrm{O}(2 \%)$, in January and July 2008.

\begin{tabular}{rrrrrrr}
\hline & $T_{\mathrm{S}}$ & $T$ & $\mathrm{H}_{2} \mathrm{O}$ & $\mathrm{N}_{2} \mathrm{O}$ & 4 Variables \\
\hline \multirow{4}{*}{ AIRS } & \multirow{2}{*}{ Jan 2008 } & 0.04 & -0.02 & -0.02 & 0.00 & 0.01 \\
\cline { 3 - 7 } & \multirow{2}{*}{ Jul 2008 } & 1.28 & 1.24 & 1.61 & 0.28 & 2.38 \\
\hline \multirow{4}{*}{ IASI } & 0.10 & 0.01 & -0.01 & 0.00 & 0.10 \\
& & 2.12 & 1.16 & 1.02 & 0.26 & 2.62 \\
\cline { 3 - 7 } & \multirow{2}{*}{ Jan 2008 } & -0.05 & -0.07 & 0.00 & 0.01 & -0.10 \\
& & 0.89 & 1.64 & 0.58 & 1.33 & 2.35 \\
\hline
\end{tabular}

is bigger and the standard deviations can reach 2 ppbv. This comes from the bigger sensitivity to $T_{\mathrm{S}}$ of the AIRS couples (see Table 1).

The influence of $\mathrm{N}_{2} \mathrm{O}$ is more important for IASI than for AIRS, due to a lower sensitivity to $\mathrm{N}_{2} \mathrm{O}$ of AIRS couples. The differences between the "modified CO" and the "reference CO" are on average quasi null with standard deviations of about $1.3 \mathrm{ppbv}$ for IASI and about $0.3 \mathrm{ppbv}$ for AIRS. $\mathrm{N}_{2} \mathrm{O}$ slightly perturbs the BT of IASI channels and, as shown in Table 2, the difference of sensitivities to $\mathrm{N}_{2} \mathrm{O}$ has the same sign for each couple. Thus, there is no compensation of the $\mathrm{N}_{2} \mathrm{O}$ effect on $\mathrm{CO}$ between the three couples, which could induce a small systematic bias.

Last, the influence of water vapour on the $\mathrm{CO}$ retrievals is very weak for IASI, with quasi null average differences and standard deviations of less than $0.6 \mathrm{ppbv}$. The influence of water vapour on AIRS CO retrievals is more important. The average differences are almost null, but standard deviations can reach $1.6 \mathrm{ppbv}$. The difference of sensitivities to $\mathrm{H}_{2} \mathrm{O}$ has the same sign for each AIRS couple, so here there is no compensation between the couples.

\subsection{Comparison with CARIBIC}

AIRS and IASI CO retrievals are compared to CARIBIC CO measurements (Brenninkmeijer et al., 2007; Scharffe et al., 2012). While analysing the results of this comparison, one has to keep in mind that CARIBIC measures $\mathrm{CO}$ at a given altitude in the range 9-12 km, whereas an integrated content of tropospheric CO is retrieved from AIRS and IASI (see Sect. 4.3). Use is made of CARIBIC measurements from a total of 104 flights made over four different tropical regions from July 2007 to July 2011: China, India, Africa and the Caribbean. Six examples of flights and corresponding AIRS and IASI orbits are shown in Fig. 4. More FOVs are available for AIRS than for IASI (see Sect. 2) yielding somehow denser orbits. Over Africa, measurements are available between $30^{\circ} \mathrm{N}$ and $30^{\circ} \mathrm{S}$. The three flights shown in Fig. 4a-c took place in October 2009 and November and
December 2010, which are transition months between the fire seasons in the Southern Hemisphere (SH) and in the Northern Hemisphere $(\mathrm{NH})$. A good agreement is seen between CARIBIC measurements and AIRS and IASI CO for all latitudes: low values are found for higher latitudes with $\mathrm{CO}$ increasing progressively while getting closer to the equator; a good agreement is also seen over the Saharian desert, which is a region characterised by a strong variability in emissivity. The same patterns are found with CARIBIC, AIRS and IASI: (i) in October, values above $110 \mathrm{ppbv}$ are only found in $\mathrm{SH}$, near $10^{\circ} \mathrm{S}$, by CARIBIC, AIRS and IASI; (ii) in November, such values are found both in $\mathrm{NH}$ and $\mathrm{SH}$, but with still higher values in $\mathrm{SH}$; (iii) in December, they are mostly concentrated near the equator. For flight 321 (12 December 2010) CARIBIC measured very high values between $5^{\circ} \mathrm{S}$ and $5^{\circ} \mathrm{N}$, reaching sometimes more than $200 \mathrm{ppbv}$, that are not seen by AIRS or IASI. This can be explained by the lack of $\mathrm{CO}$ retrievals near the equator due to the presence of clouds, and also by the fact that there is a time shift between the flights and the satellites passings which matters particularly near such time-dependant sources as fires. For flight 321 , the aircraft passed about $3.5 \mathrm{~h}$ before and $8 \mathrm{~h}$ after the nearest two IASI orbits, and about $8 \mathrm{~h}$ before and $4 \mathrm{~h}$ after the nearest AIRS ones.

Over the Atlantic Ocean (Fig. 4d), comparison with flight 286 (23 September 2009) north-east of South America highlights that smaller variations than in Africa are seen along the flight by the sounders and CARIBIC. A steep increase occurs at the end of the flight near $12^{\circ} \mathrm{S}$, where no AIRS or IASI retrievals are available; however, the latitudinal gradient seen along the flight track is well-seen by the sounders around $50^{\circ} \mathrm{W}$. Finally, over India (Fig. 4e) for flight 228 (23 April 2008), and China (Fig. 4f) for flight 210 (24 October 2007), two mountainous regions, the evolution of $\mathrm{CO}$ along the flights is also quite well reproduced. Over China, one AIRS orbit exhibits particularly high $\mathrm{CO}$ values, reaching $140 \mathrm{ppbv}$, that are not seen by CARIBIC; the time lags between the sounder and the flight, that matter particularly in such a polluted area, might explain this discrepancy.

More quantitatively, agreement between AIRS/IASI CO and CARIBIC $\mathrm{CO}$ is assessed by colocating in time and space CARIBIC and AIRS/IASI CO. For this, CARIBIC $\mathrm{CO}$ data are averaged over $1^{\circ}$ along the flight track and colocalised with $1^{\circ} \times 1^{\circ}$ average AIRS and IASI retrievals. For the comparisons, only aircraft measurements higher than $5 \mathrm{~km}$ altitude, to be far enough from the sources and close to the altitude seen by the sounders are selected. We have checked that above $5 \mathrm{~km}$, there is no correlation between the altitude of the aircraft and the difference between the aircraft and the sounders measurements; so, in order to have better statistics, only CARIBIC data that are in the range 5$12 \mathrm{~km}$ are kept. Additionally, time gap between the aircraft and AIRS or IASI have to be less than five hours, and at least 5 AIRS or IASI FOVs 5 are required in each grid cell. Figure 5 shows CARIBIC $\mathrm{CO}$ against AIRS and IASI CO and 
Table 7. Comparisons between CARIBIC and AIRS (upper part) and IASI (lower part). Average of the difference CARIBIC-AIRS or CARIBIC-IASI, standard deviation of the difference, linear correlation coefficient, average relative difference and number of colocated $1^{\circ} \times 1^{\circ}$ grid cells, over the period (July 2007-June 2011) (60 flights for AIRS and 57 flights for IASI), for each season and for the whole year.

\begin{tabular}{llrrrrr}
\hline & $\begin{array}{r}\text { CARIBIC-Sounder } \\
(\mathrm{ppbv})\end{array}$ & $\begin{array}{r}\text { Std } \\
(\mathrm{ppbv})\end{array}$ & $r$ & $\begin{array}{r}\text { Rel. diff. } \\
(\%)\end{array}$ & $\begin{array}{r}\text { No. of } \\
\text { grid cells }\end{array}$ \\
\hline \multirow{4}{*}{ AIRS } & Whole year & 6.1 & 18.4 & 0.71 & 4.9 & 483 \\
& DJF & 10.1 & 20.2 & 0.80 & 7.7 & 125 \\
& MAM & 6.4 & 24.5 & 0.44 & 4.3 & 120 \\
& JJA & 3.0 & 11.5 & 0.54 & 3.5 & 143 \\
& SON & 5.3 & 13.7 & 0.88 & 1.3 & 95 \\
\hline \multirow{4}{*}{ IASI } & Whole year & 3.6 & 13.0 & 0.77 & 3.4 & 478 \\
& DJF & 1.1 & 11.3 & 0.80 & 1.1 & 60 \\
& MAM & 3.4 & 20.7 & 0.78 & 0.9 & 95 \\
& JJA & 5.7 & 8.9 & 0.82 & 6.7 & 140 \\
& SON & 2.9 & 10.5 & 0.78 & 3.0 & 183 \\
\hline
\end{tabular}
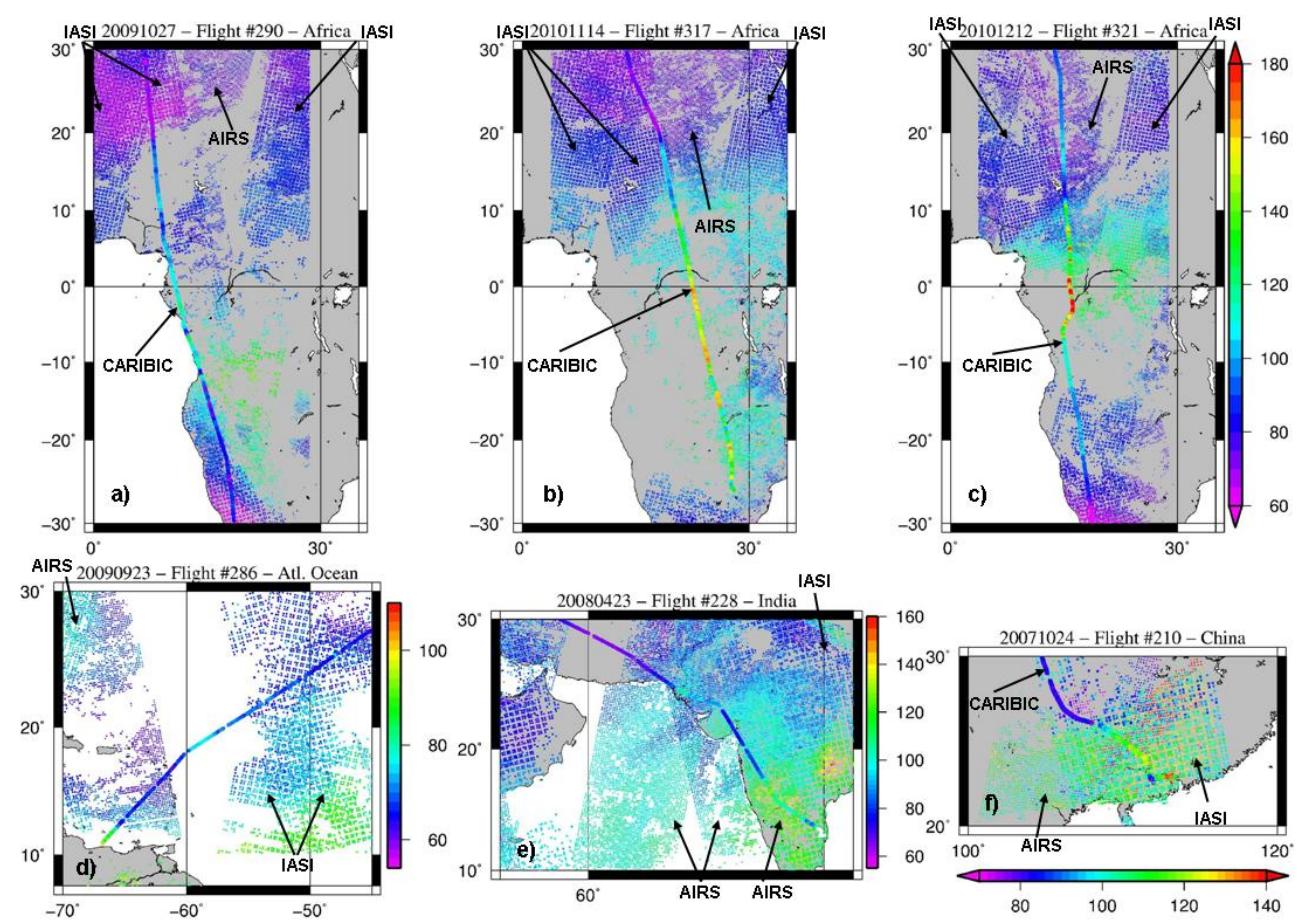

Fig. 4. CO measured by CARIBIC aircrafts at $\sim 10 \mathrm{~km}$ altitude for 6 flights over Africa (a, b, c), the Atlantic Ocean (d), India (e) and China (f), and corresponding AIRS and IASI mid-tropospheric content of CO (ppbv).

the associated regression lines. The corresponding linear correlation coefficients $(r)$ are given in Table 7, together with the biases, standard deviations and average relative differences between CARIBIC CO and the retrieved CO. The relative difference is defined as followed (e.g., Pommier et al., 2010):

relative difference $=\frac{(\text { CARIBIC }- \text { Sounder }) \times 2}{(\text { CARIBIC }+ \text { Sounder })}$

The difference between CARIBIC and AIRS is on average $6.1 \mathrm{ppbv}$, with a standard deviation of $18.4 \mathrm{ppbv}$ and a relative difference of $4.9 \%$. The correlation coefficient is 0.71 . The agreement between CARIBIC and IASI is better, with a difference of $3.6 \mathrm{ppbv}$ and a standard deviation of $13.0 \mathrm{ppbv}$. The relative difference is also smaller, reaching $3.4 \%$, and the correlation coefficient is higher (0.77). Some differences are found between each season. For MarchApril-May (MAM), the standard deviation is higher than $20 \mathrm{ppbv}$ for AIRS and IASI but the relative error is lower than the one for most of the other seasons, due to the high $\mathrm{CO}$ background. Indeed, differences above $40 \mathrm{ppbv}$ are found over Africa and China where CARIBIC saw several extreme 

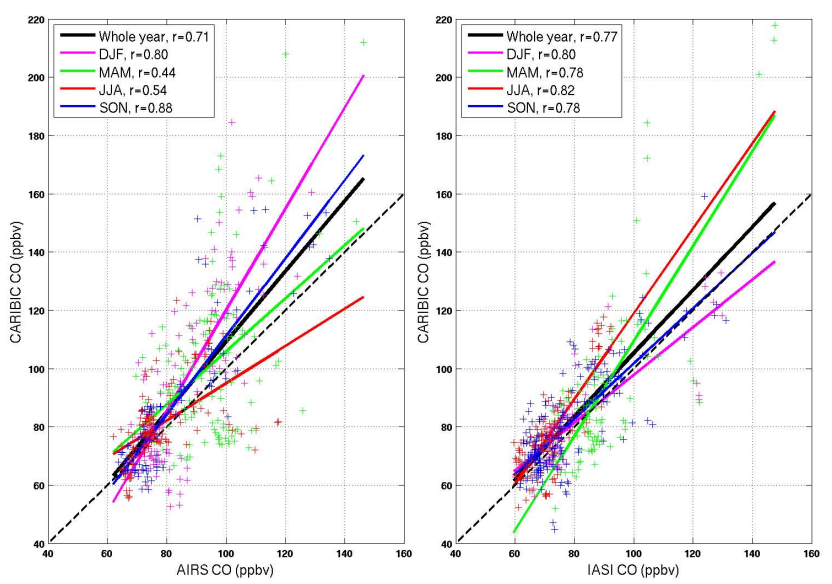

Fig. 5. Scatter plots of $1^{\circ} \times 1^{\circ}$ averaged CARIBIC and AIRS (left) and IASI (right) CO. The coloured lines represent the linear regression between the data for each season (pink: December-JanuaryFebruary, green: March-April-May, red: June-July-August, blue: September-October-November) and the black line for all seasons. The black dashed line gives the $1: 1$ line.

events that were not seen by AIRS and IASI. This is also the case in December-January-February (DJF). Especially over Southeast China such events are frequently encountered by the CARIBIC aircraft (Lai et al., 2011). In June-July-August (JJA), a smaller standard deviation is found corresponding to a higher relative error, due to low $\mathrm{CO}$ and an absence of strong emissions. The better agreement between CARIBIC and IASI can be attributed to the better suitability of IASI to retrieve $\mathrm{CO}$, stemming from its spectral characteristics (see Sect. 3.1).

\subsection{AIRS and IASI retrievals}

Maps of monthly means of AIRS and IASI retrieved columns of CO are plotted in Fig. 6 for January, April, July and October 2008. White areas denote lack of observations due to persistent cloudiness. Some areas seen by IASI are not seen by AIRS due to a too restrictive cloud detection scheme used for AIRS. The maps show a very good agreement between AIRS and IASI in terms of oceanic background values and spatial distribution over land. The extreme concentrations of CO located in northern Africa in January and April and in southern Africa in July and October are a consequence of strong biomass fires occurring there during the dry seasons. High concentrations west of these burning areas in the Atlantic and also South-East in October over the Indian Ocean highlight the transport pathways of fire emissions (Guan et al., 2008). Fire emissions are also seen over South America, with a small signal in the North in April and a much bigger one in Amazonia in October, with transported emissions over the Atlantic (Freitas et al., 2006). In Asia, high CO values are found in India and South-East Asia with fire emissions spreading in the Indian Ocean in January; in April, emissions
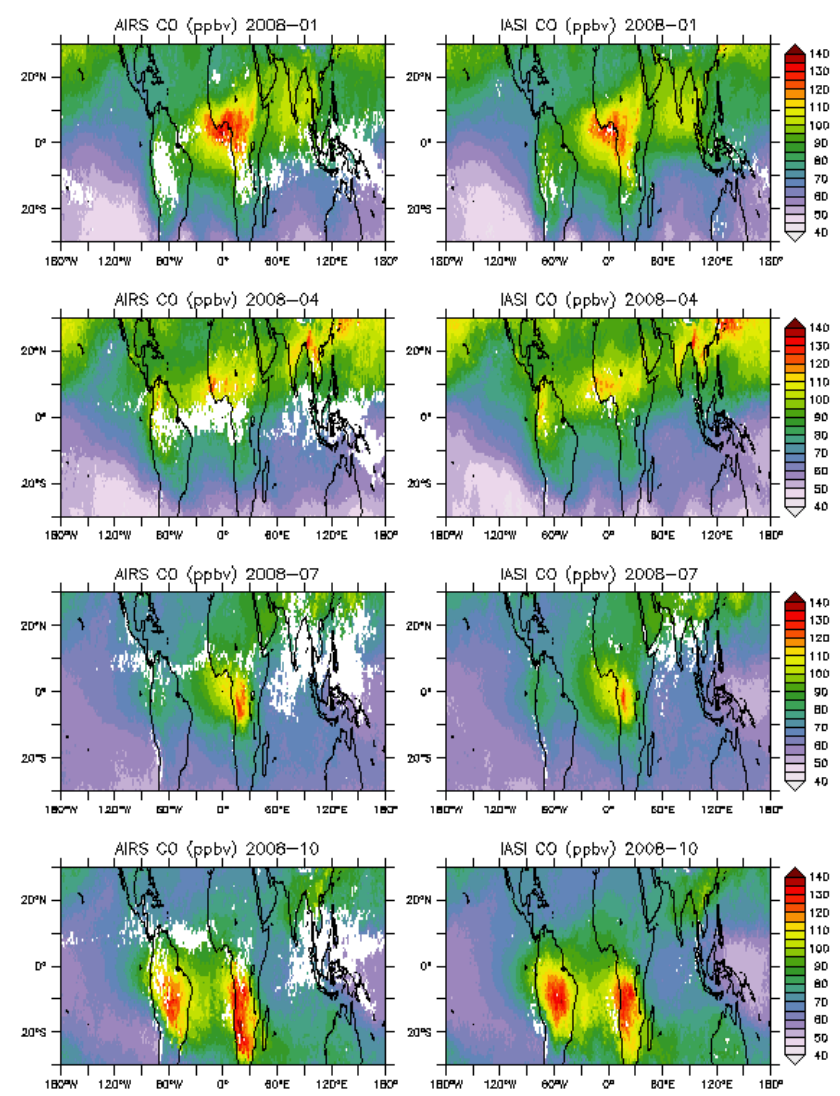

Fig. 6. AIRS (left) and IASI (right) monthly average midtropospheric CO (ppbv) for January, April, July and October 2008. Blank zones correspond to persistent cloudiness.

are stronger in China and are transported over the Pacific Ocean. In July and October, relatively high CO values are still located over China, due to persistent pollution. Independently of these extreme values, there is a sharp south-north gradient of CO in January and April, explained by strongest continuous pollution sources located in the Northern Hemisphere and the seasonality of the OH sink (Holloway et al., 2000).

The evolution of tropospheric $\mathrm{CO}$ over land from July 2007 to June 2011 is seen in Fig. 7 for the tropical regions. AIRS and IASI display the same evolution of $\mathrm{CO}$ during this period in terms of seasonality, seasonal amplitudes and year-to-year variability. The average difference between AIRS and IASI, computed over colocated daily means over the whole period, is $0.5 \mathrm{ppbv}$, with standard deviation of $3.5 \mathrm{ppbv}$. It is expected that a part of the discrepancy between AIRS and IASI comes from the different time passings of the instruments. $\mathrm{CO}$ is higher during winter, reaching a maximum at the end of the dry season, in March or April in $\mathrm{NH}$, and in October in SH. The background level of $\mathrm{CO}$ is higher in the North, whereas the amplitude of the seasonal cycle is higher in the southern tropics due to stronger fire emissions. Consequently, the year-to-year variability is much lower in 

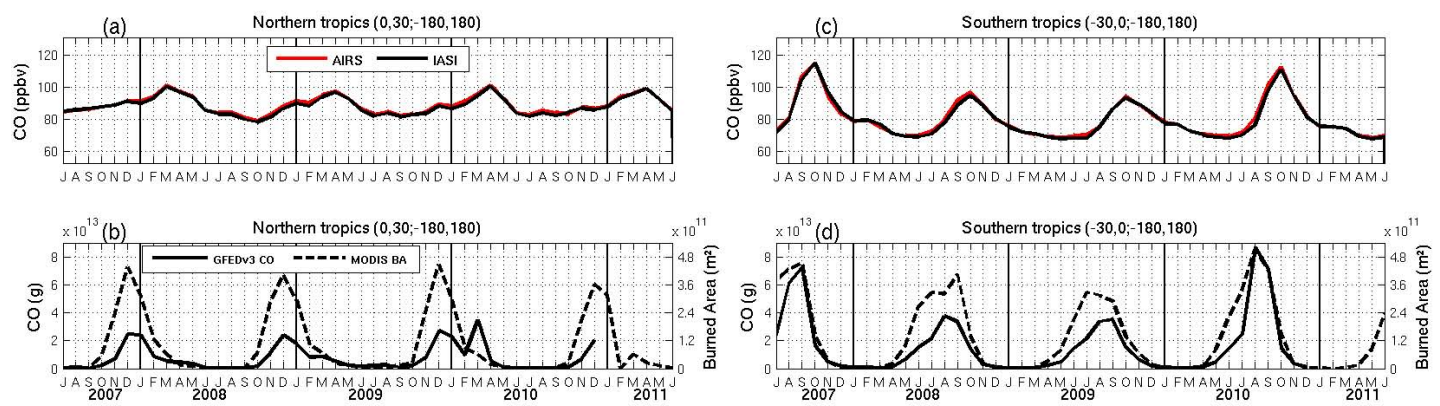

Fig. 7. (a) Time series of AIRS (red) and IASI (black) CO over land, for the northern tropics. (b) Time series of GFEDv3 CO emissions (solid line) and MODIS Burned Area (dashed line) for the northern tropics. (c) and (d) same as (a) and (b), respectively, for the southern tropics.
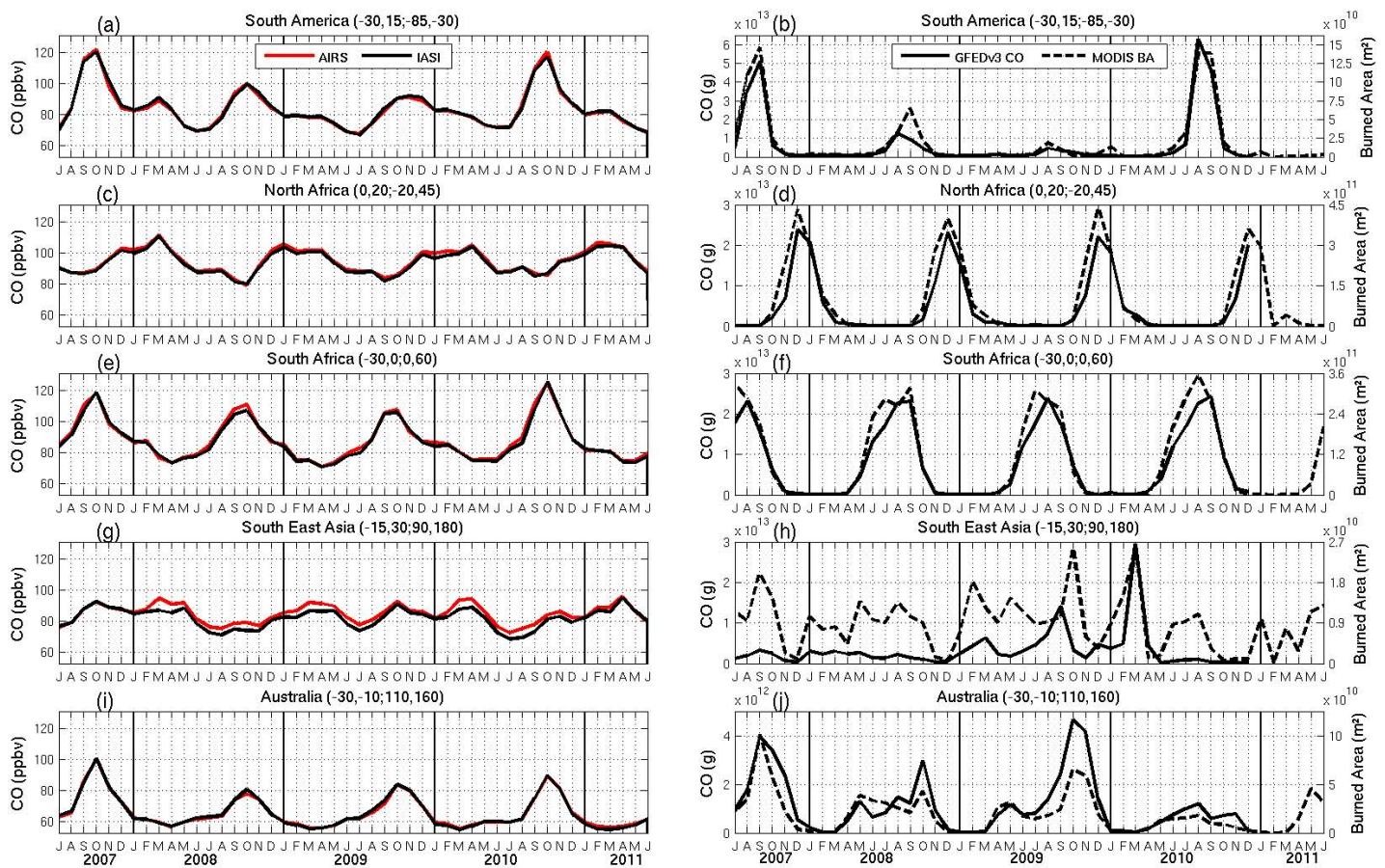

Fig. 8. Same as Fig. 7 for 5 tropical areas: South America $(\mathbf{a}, \mathbf{b})$, North Africa (c, d), South Africa (e, f), South East Asia (g, h) and Australia (i, j). Coordinates of the areas are given as follow: (latitude S, latitude N; longitude W, longitude E).

$\mathrm{NH}$ than in $\mathrm{SH}$, where an increase in maximum $\mathrm{CO}$ values occurred in 2010, following a decrease after 2007 (see below). Figure 7 also shows the evolution of the GFEDv3 CO fire emissions (van der Werf et al., 2010) and the MODIS Burned Area (BA) (Roy et al., 2008) for the same period and the same area. In $\mathrm{NH}$, the maximum of the BA and the emissions happens in December, with a secondary peak in March, whereas a little increase in CO is seen in December or January, and the maximum reached in March or April. In $\mathrm{SH}$, fires are active between May and November, reaching a maximum of activity around August; according to AIRS and IASI, the maximum of $\mathrm{CO}$ in the troposphere is reached two months later.
The good match between these two fire products and $\mathrm{CO}$ concentrations confirms that the evolution of tropospheric $\mathrm{CO}$ in the tropics is mostly driven by fire activity (Duncan and Logan, 2008). The excess of CO in the troposphere seen by AIRS and IASI has the same duration as the fire season, but with a shift of about two months in the Southern Hemisphere. This has already been observed for southern Africa (Edwards et al., 2006; van der Werf et al., 2006; Roberts et al., 2009), where it might be explained by the predominance of woodland burning at the end of the dry season. Moreover, $\mathrm{CO}$ is emitted mostly in the smoldering phase of the combustion (Lobert and Warnatz, 1993), which implies conditions of higher moisture and lower temperature found at the end of the dry season. In the Northern Hemisphere, the shift 

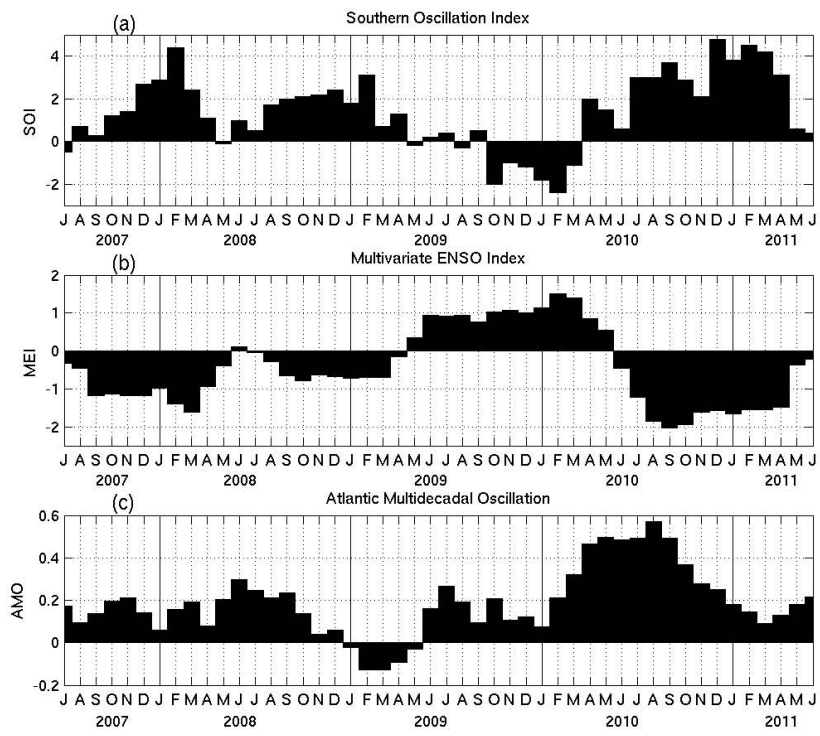

Fig. 9. Climate indexes for the period July 2007-June 2011. (a) Southern Oscillation Index. (b) Multivariate ENSO Index. (c) Atlantic Multidecadal Oscillation. The data come from the ESRL/NOAA.

is of about four months. The influence of biomass burning is less important than in the South, because of weaker fire emissions and the influence of pollution from higher latitudes.

Figure 8 shows the evolution of $\mathrm{CO}$ and fire activity, respectively, for five tropical areas where strong biomass burning takes place every year. In South America (Fig. 8a and b) the excess of $\mathrm{CO}$ is observed between August and November; according to the two fire products, the fire season occurs between June and October. A secondary CO peak is seen between February and April, caused by the smaller fire activity in January in the northern part of the area. South America has experienced a strong year-to-year variability in terms of $\mathrm{CO}$, that can be explained by the variability in fires, in relation with climate conditions. Figure 9 displays the Southern Oscillation Index (SOI), the Multivariate ENSO Index and the Atlantic Multidecadal Oscillation (AMO). The decrease in maximum CO values from 2007 to 2009 is in good agreement with the decreasing activity of fires during the same period, which was characterised by average climate conditions, as seen in Fig. 9. On the contrary, in 2010, the very high AMO coupled to the remaining El Niño conditions in the beginning of 2010 (Fig. 9) induced a severe drought in Amazonia (Lewis et al., 2011), which explains the increase in fire activity and, subsequently, the increase in $\mathrm{CO}$ concentrations.

In North Africa (Fig. 8c and d), $\mathrm{CO}$ is higher between November and May while the fire season occurs between October and February. The excess of $\mathrm{CO}$ is still important until August, which might be caused by the transport of fire emissions from southern Africa. The seasonality of $\mathrm{CO}$ in South Africa (Fig. 8e and f) can be more directly related to

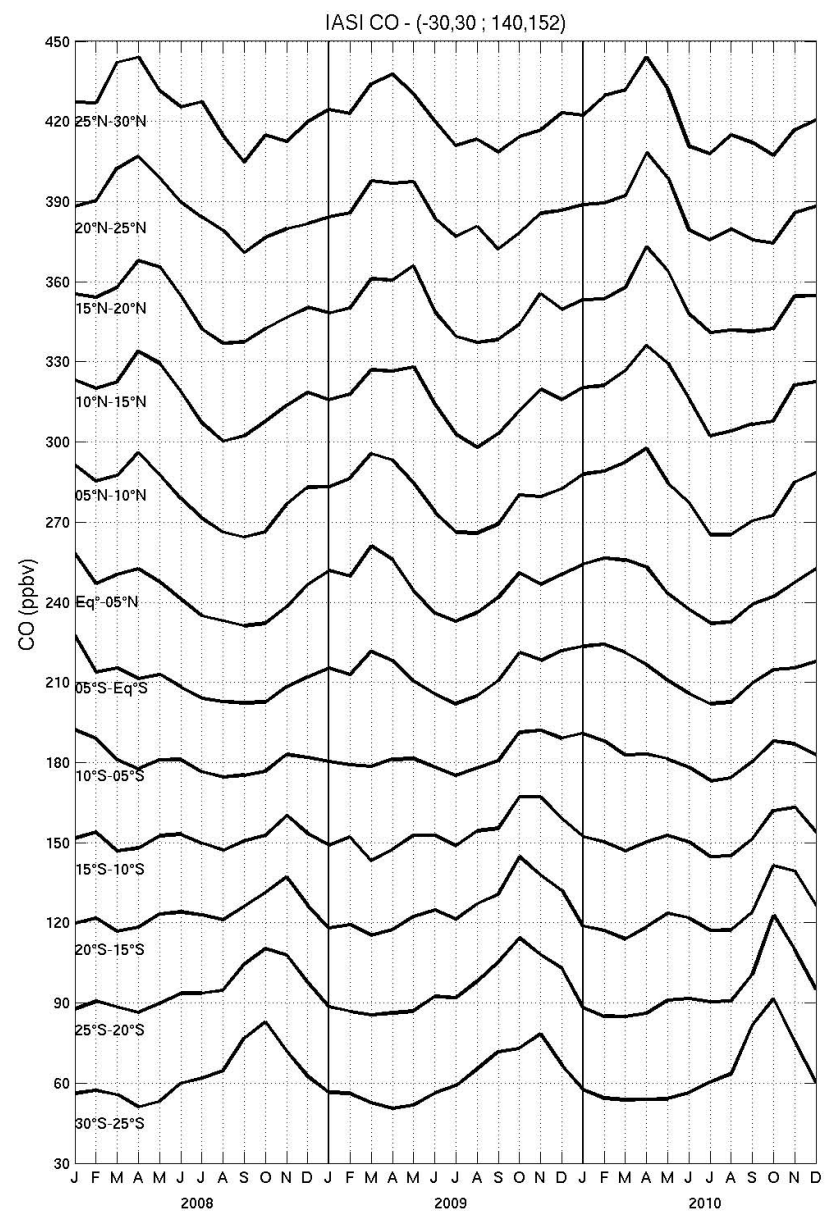

Fig. 10. IASI CO (ppbv) from $30^{\circ} \mathrm{N}$ to $30^{\circ} \mathrm{S}$ averaged over $140: 152 \mathrm{E}$ for 12 latitudinal bands of $5^{\circ}$ each. The scale corresponds to the $\left(30^{\circ} \mathrm{S}, 25^{\circ} \mathrm{S}\right)$ band; $30 \mathrm{ppbv}$ is added to each following latitudinal band. This figure can be compared to Fig. 1 of Matsueda et al. (2002).

fire activity. The excess of CO is observed between July and December, with remaining high values between January and March, revealing the impact of transported emissions from northern Africa fire emissions. As observed in South America, there is a sharp increase in maximum CO values in 2010 compared to previous years, which can be explained by the increase in the burned area observed this year in relation with ENSO (Fig. 9).

In South-East Asia (Fig. 8g and h), CO displays two maxima per year, the first one between March and May, the other one around October-November. The minimum in this region occurs around July-August. GFEDv3 shows two peaks in the emissions in 2009, in March and September, which can explain the evolution of $\mathrm{CO}$ this year. However, the high fire activity seen in March 2010 with the two fire products does not seem to have entailed a significant change in $\mathrm{CO}$ evolution. The discrepancies between the BA and GFEDv3 suggest that fires behaviour is somehow difficult to assess in this area. 
Finally, in Australia (Fig. 8i and j), excess of $\mathrm{CO}$ occurs between August and December, with a maximum in October, which matches quite well fire activity. The increase in $\mathrm{CO}$ begins in May, which is again consistent with fire activity. As well as for South America and South Africa, there is a decrease in maximum CO values after 2007 and an increase of the maximum in October 2010. However, for Australia, this interannual variability does not seem to be directly supported by the variability of fires.

Figure 10 shows the monthly evolution of IASI CO for 12 latitudinal bands of $5^{\circ}$ each, over the Western Pacific between Australia and Japan, an area where aircraft measurements of CO were routinely performed between 1993 and 2001 (Matsueda et al., 1999). Matsueda et al. (2002) have shown that $\mathrm{CO}$ seasonality in this region was dependent on Indonesian fires and closely related to the ENSO events. Figure 10 shows the latitudinal variations of $\mathrm{CO}$, and can be directly compared to Fig. 1 of Matsueda et al. (2002). A very good agreement in the seasonality is seen at all latitudes when comparing both figures. The highest seasonal amplitude of $\mathrm{CO}$ is found near $25^{\circ}$ North and South, but the background level is higher in the North, reaching $80 \mathrm{ppbv}$ for $\left(25^{\circ} \mathrm{N}, 30^{\circ} \mathrm{N}\right)$ whereas it is about $50 \mathrm{ppbv}$ for $\left(30^{\circ} \mathrm{S}, 25^{\circ} \mathrm{S}\right)$. In the Northern Hemisphere, $\mathrm{CO}$ is maximum in April while it is minimum in the South; the maximum in the South occurs in October-November while it reaches a minimum in the North. Figure 10 also shows an increase in maximum $\mathrm{CO}$ values in 2010, at the beginning of the year in NH. Early 2010 shows El Niño conditions that may have caused the large increase in fire emissions seen from GFEDv3 in Fig. 8h. There is also an increase at the end of the year in $\mathrm{SH}$ although MODIS BA and GFEDv3 do not report significant increase in fire activity.

\section{Conclusions}

Four years (July 2007-June 2011) of tropospheric CO columns have been retrieved from AIRS and IASI observations in the tropics $\left(30^{\circ} \mathrm{S}, 30^{\circ} \mathrm{N}\right)$. The retrieval method is based on a double differential approach: differences between channels which have the same sensitivities to every atmospheric and surface variable but $\mathrm{CO}$; differences between observations and simulations, using the $4 \mathrm{~A}$ radiative transfer model and the ECMWF reanalyses. The sensitivity to surface temperature $\left(T_{\mathrm{s}}\right)$ cancels out when taking the BT differences which limits its influence on the retrieved CO signal; however, $T_{\mathrm{S}}$ still influences the part of the atmosphere seen by the sounders. The sensitivity to $\mathrm{CO}$ along the vertical depends on the thermal contrast (i.e., the difference between the surface temperature and the temperature of the first pressure level): the higher the thermal contrast the higher the sensitivity to $\mathrm{CO}$ near the surface. Weighting functions associated to the mid-troposphere integrated content of $\mathrm{CO}$ retrieved from IR channels display a maximum of sensitivity around $450 \mathrm{hPa}(\sim 6.5 \mathrm{~km})$, with half the maximum between $200 \mathrm{hPa}(\sim 12 \mathrm{~km})$ and $750 \mathrm{hPa}(\sim 2.5 \mathrm{~km})$. The effects of aerosols have also been assessed on $\mathrm{CO}$ retrieval using simulations based on the 4A/DISORT model. For both smoke and dust aerosols, their impact almost cancels out when taking the BT differences, the resulting effect on the $\mathrm{CO}$ retrievals being for less than $1 \mathrm{ppbv}$. The retrieval process has been shown to be weakly sensitive to the atmospheric and surface input data, with an associate bias in $\mathrm{CO}$ less than $0.10 \mathrm{ppbv}$ and a standard deviation less than 3 ppbv.

AIRS and IASI retrievals have been compared to CARIBIC aircraft measurements. Relative differences are found to be $4.9 \%$ and $3.4 \%$ for AIRS and IASI, respectively, with coefficients of correlation of 0.71 and 0.77 . The better agreement between CARIBIC and IASI comes from its better spectral resolution, which helps discriminating $\mathrm{CO}$ from other signals, and the coverage of the full $\mathrm{CO}$ absorption band (which yields channels characterised by stronger sensitivity to $\mathrm{CO}$ ). The twice lower noise of AIRS compared to IASI does not compensate for this difference in terms of spectral resolution $\left(1.8 \mathrm{vs} .0 .5 \mathrm{~cm}^{-1}\right)$. This indicates that an improvement of both spectral and radiometric characteristics should be a priority for future instruments. Further comparisons with other $\mathrm{CO}$ retrievals from TIR sounders will be performed in the future. As stressed for example by George et al. (2009), these comparisons require to take into account the differences between the retrievals in the a priori and the vertical sensitivities, which would constitute a study on its own.

AIRS and IASI CO show a very good agreement in terms of seasonality, seasonal amplitudes, interannual variability and spatial distribution, as well as in terms of absolute value. The average difference between both instruments over the $4 \mathrm{yr}$ period is $0.5 \mathrm{ppbv}$, with standard deviation of $3.5 \mathrm{ppbv}$. The $\mathrm{CO}$ evolution in the tropics is mostly driven by fire emissions. In the northern tropics, where the background level of $\mathrm{CO}$ is higher than in the southern tropics, there have not been any important internannual variations in $\mathrm{CO}$ because no major changes took place over the $4 \mathrm{yr}$ period studied here. On the contrary, the southern tropics, where stronger fire events take place, display a strong interannual variability, with a sharp decrease after 2007 followed by a large increase in 2010 in relation with El Niño conditions in early 2010 and the exceptionally high AMO throughout 2010.

Using both AIRS and IASI, whose Equator crossing-times are, respectively, 01:30 and 09:30 a.m./p.m. LT, gives access to four $\mathrm{CO}$ retrievals a day highlighting the great possibility of studying the diurnal cycle of $\mathrm{CO}$ from infrared sounders onboard polar satellites. Moreover, infrared sounders also enable to retrieve several gases emitted by fires, either $\mathrm{CO}_{2}$ or reactive trace species (Crevoisier et al., 2009; Coheur et al., 2009), giving the opportunity to study the correlations between all these gases from a single instrument. This possibility will be assured in the future with observations from the Fourier transform spectrometer CrIS (Cross-track Infrared Sounder) launched onboard the NPP (National Polar-orbiting 
Partnership) satellite in October 2011, and with the launches of MetOp-B in September 2012 and MetOp-C in 2017, providing us with more than $20 \mathrm{yr}$ of IASI observations.

Acknowledgements. Thibaud Thonat is supported by Centre National d'Etudes Spatiales (CNES, France) and Microsoft Research Ltd. This work has also been supported by the Agence Nationale de la Recherche under contract 2010 BLAN 61101 "TropFire", and the European Union's Seventh Framework Programme (FP7/2007-2013) under Grant Agreement no. 218793 (MACC project). IASI has been developed and built under the responsibility of CNES. It is flown onboard the MetOp satellites as part of the EUMETSAT Polar System. The IASI L1 data are received through the EUMETCast near real time data distribution service. We particularly wish to thank the ETHER centre team for their help in getting IASI data. Calculations were performed using the resources of IDRIS, the computing centre of CNRS, of ECMWF and of the IPSL data and computing centre ClimServ.

Edited by: T. von Clarmann

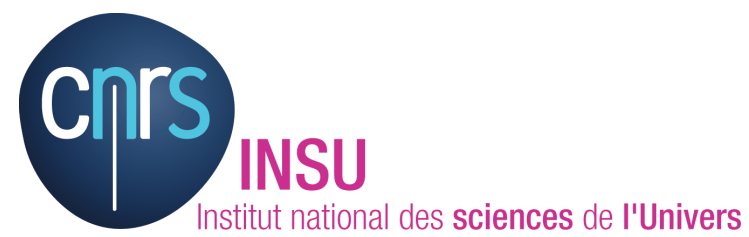

The publication of this article is financed by CNRS-INSU.

\section{References}

Brenninkmeijer, C. A. M., Crutzen, P., Boumard, F., Dauer, T., Dix, B., Ebinghaus, R., Filippi, D., Fischer, H., Franke, H., Frieß, U., Heintzenberg, J., Helleis, F., Hermann, M., Kock, H. H., Koeppel, C., Lelieveld, J., Leuenberger, M., Martinsson, B. G., Miemczyk, S., Moret, H. P., Nguyen, H. N., Nyfeler, P., Oram, D., O'Sullivan, D., Penkett, S., Platt, U., Pupek, M., Ramonet, M., Randa, B., Reichelt, M., Rhee, T. S., Rohwer, J., Rosenfeld, K., Scharffe, D., Schlager, H., Schumann, U., Slemr, F., Sprung, D., Stock, P., Thaler, R., Valentino, F., van Velthoven, P., Waibel, A., Wandel, A., Waschitschek, K., Wiedensohler, A., Xueref-Remy, I., Zahn, A., Zech, U., and Ziereis, H.: Civil Aircraft for the regular investigation of the atmosphere based on an instrumented container: The new CARIBIC system, Atmos. Chem. Phys., 7, 4953-4976, doi:10.5194/acp-7-4953-2007, 2007.

Buchwitz, M., de Beek, R., Bramstedt, K., Noël, S., Bovensmann, H., and Burrows, J. P.: Global carbon monoxide as retrieved from SCIAMACHY by WFM-DOAS, Atmos. Chem. Phys., 4, 19451960, doi:10.5194/acp-4-1945-2004, 2004.

Capelle, V., Chédin, A., Péquignot, E., Schluessel, P., Newman, S. M., and Scott, N. A.: Infrared continental surface emissivity spectra and skin temperature retrieved from IASI observations over the tropics, J. Appl. Meteorol. Clim., 51, 1164-1179, doi:10.1175/JAMC-D-11-0145.1, 2012.

Chédin, A., Scott, N. A., Wahiche, C., and Moulinier, P.: The improved initialization inversion method: a high resolution physical method for temperature retrievals from satellites of the TIROS-N series, J. Clim. Appl. Meteorol., 24, 128-143, 1985.

Chédin, A., Serrar, S., Scott, N. A., Pierangelo, C., and Ciais, P.: Impact of tropical biomass burning emission on the diurnal cycle of upper tropospheric $\mathrm{CO} 2$ retrieved from NOAA 10 satellite observations, J. Geophys. Res., 110, D11309, doi:10.1029/2004JD005540, 2005.

Chevallier, F., Chéruy, F., Scott, N. A., and Chédin, A.: A neural network approach for a fast and accurate computation of longwave radiative budget, J. Appl. Meteorol., 37, 1385-1397, 1998.

Chéruy, F., Scott, N. A., Armante, R., Tournier, B., and Chédin, A.: Contribution to the development of radiative transfer models for high spectral resolution observations in the infrared, J. Quant. Spectrosc. Ra., 53, 597-611, 1995.

Clerbaux, C., Hadji-Lazaro, J., Payan, S., Camy-Peyret, C., and Mégie, G.: Retrieval of CO Columns from IMG/ADEOS Spectra, IEEE T. Geosci. Remote, 37, 1657-1661, 1999.

Coheur, P.-F., Clarisse, L., Turquety, S., Hurtmans, D., and Clerbaux, C.: IASI measurements of reactive trace species in biomass burning plumes, Atmos. Chem. Phys., 9, 5655-5667, doi:10.5194/acp-9-5655-2009, 2009.

Crevoisier, C., Chédin, A., and Scott, N. A.: AIRS channel selection for $\mathrm{CO}_{2}$ and other trace-gas retrievals, Q. J. Roy. Meteorol. Soc., 129, 2719-2740, 2003.

Crevoisier, C., Chédin, A., Matsueda, H., Machida, T., Armante, R., and Scott, N. A.: First year of upper tropospheric integrated content of $\mathrm{CO}_{2}$ from IASI hyperspectral infrared observations, Atmos. Chem. Phys., 9, 4797-4810, doi:10.5194/acp-9-4797-2009, 2009.

de Laat, A. T. J., Gloudemans, A. M. S., Schrijver, H., van den Broek, M. M. P., Meirink, J. F., Aben, I., and Krol, M.: Quantitative analysis of SCIAMACHY carbon monoxide total column measurements, Geophys. Res. Lett., 33, L07808, doi:1029/2005GL025530, 2006.

Dee, D. P., Uppala, S. M., Simmons, A. J., Berrisford, P., Poli, P., Kobayashi, S., Andrea, U., Balmaseda, M. A., Balsamo, G., Bauer, P., Bechtold, P., Beljaars, A. C. M., van de Berg, L., Bidlot, J., Bormann, N., Delsol, C., Dragani, R., Fuentes, M., Geer, A. J., Haimberger, L., Healy, S. B., Hersbach, H., Hólm, E. V., Isaksen, L., Kållberg, P., Köhler, M., Matricardi, M., McNally, A. P., Monge-Sanz, B. M., Morcrette, J.-J., Park, B.-K., Peubey, C., de Rosnay, P., Tavolato, C., Thépaut, J.-N., and Vitart, F.: The ERA-Interim reanalysis: configuration and performance of the data assimilation system, Q. J. Roy. Meteorol. Soc., 137, 553597, doi:10.1002/qj.828, 2011.

Deeter, M. N., Emmons, L. K., Francis, G. L., Edwards, D. P., Gille, J. C., Warner, J. X., Khattatov, B., Ziskin, D., Lamarque, J.-F., Ho, S.-P., Yudin, V., Attié, J.-L., Packman, D., Chen, J., Mao, D., and Drummond, J. R.: Operational carbon monoxide retrieval algorithm and selected results for MOPITT instrument, J. Geophys. Res., 108, ACH1-1-ACH-1-11, doi:10.1029/2002JD003186, 2003.

Deeter, M. N., Edwards, D. P., Gille, J. C., and Drummond, J. R.: Sensitivity of MOPITT observations to carbon monoxide in the mower troposphere, J. Geophys. Res., 112, D24306, doi:10.1029/2007JD008929, 2007.

Deeter, M. N., Edwards, D. P., Gille, J. C., and Drummond, J. R.: CO retrievals based on MOPITT near-infrared observations, J. Geophys. Res., 114, D04303, doi:10.1029/2008JD010872, 2009. 
Duncan, B. N. and Logan, J. A.: Model analysis of the factors regulating the trends and variability of carbon monoxide between 1988 and 1997, Atmos. Chem. Phys., 8, 7389-7403, doi:10.5194/acp-8-7389-2008, 2008.

Duncan, B. N., Logan, J. A., Bey, I., Megretskaia, I. A., Yantosca, R. M., Novelli, P. C., Jones, N. B., and Rinsland, C. P.: Clobal budget of CO, 1988-1997: Source estimates and validation with a global model, J. Geophys. Res., 112, D22301, doi:1029/2007JD008459, 2007.

Edwards, D. P., Emmons, L. K., Hauglustaine, D. A., Chu, D. A., Gille, J. C., Kaufman, Y. J., Pétron, G., Yurganov, L. N., Giglio, L., Deeter, M. N., Yudin, V., Ziskin, D. C., Warner, J., Lamarque, J.-F., Francis, G. L., Ho, S. P., Mao, D., Chen, J., Grechko, E. I., and Drummond, J. R.: Observations of carbon monoxide and aerosols from Terra satellite: Northern Hemisphere variability, J. Geophys. Res., 109, D24202, doi:10.1029/2004JD004727, 2004.

Edwards, D. P., Emmons, L. K., Gille, J. C., Chu, A., Attié, J.-L., Giglio, L., Wood, S. W., Haywood, J., Deeter, M. N., Massie, S. T., Ziskin, D. C., and Drummond, J. R.: Satellite-observed pollution from Southern Hemisphere biomass burning, J. Geophys. Res., 111, D14312, doi:10.1029/2005JD006655, 2006.

Fortems-Cheney, A., Chevallier, F., Pison, I., Bousquet, P., Szopa, S., Deeter, M. N., and Clerbaux, C.: Ten years of $\mathrm{CO}$ emissions as seen from Measurements of Pollution in the Troposphere (MOPITT), J. Geophys. Res., 116, D05304, doi:10.1029/2010JD014416, 2011.

Frankenberg, C., Platt, U., and Wagner, T.: Retrieval of CO from SCIAMACHY onboard ENVISAT: detection of strongly polluted areas and seasonal patterns in global $\mathrm{CO}$ abundances, Atmos. Chem. Phys., 5, 1639-1644, doi:10.5194/acp-5-1639-2005, 2005.

Freitas, S. R., Longo, K. M., and Andreae, M. O.: Impact if including the plume rise of vegetation fires in numerical simulations of associated atmospheric pollutants, Geophys. Res. Lett., 33, L17808, doi:10.1029/2006GL026608, 2006.

George, M., Clerbaux, C., Hurtmans, D., Turquety, S., Coheur, P.F., Pommier, M., Hadji-Lazaro, J., Edwards, D. P., Worden, H., Luo, M., Rinsland, C., and McMillan, W.: Carbon monoxide distributions from the IASI/METOP mission: evaluation with other space-borne remote sensors, Atmos. Chem. Phys., 9, 8317-8330, doi:10.5194/acp-9-8317-2009, 2009.

Guan, H., Chatfield, R. B., Freitas, S. R., Bergstrom, R. W., and Longo, K. M.: Modeling the effect of plume-rise on the transport of carbon monoxide over Africa with NCAR CAM, Atmos. Chem. Phys., 8, 6801-6812, doi:10.5194/acp-8-6801-2008, 2008.

Hess, M., Koepke, P., and Schult, I.: Optical Properties of Aerosols and Clouds: The software package OPAC, B. Am. Meteorol. Soc., 79, 831-844, 1998.

Hilton, F., Armante, R., August, T., Barnet, C., Bouchard, A., Camy-Peyret, C., Capelle, V., Clarisse, L., Clerbaux, C., Coheur, P.-F., Collard, A., Crevoisier, C., Dufour, G., Edwards, D., Faijan, F., Fourrié, N., Gambacorta, A., Goldberg, M., Guidard, V., Hurtmans, D., Illingworth, S., Jacquinet-Husson, N., Kerzenmacher, T., Klaes, D., Lavanant, L., Masiello, G., Matricardi, M., McNally, A., Newman, S., Pavelin, E., Payan, S., Péquignot, E., Peyridieu, S., Phulpin, T., Remedios, J., Schlüssel, P., Serio, C., Strow, L., Stubenrauch, C., Taylor, J., Tobin, D., Wolf, W., and Zhou, D.: Hyperspectral Earth Observation from IASI: four years of accomplishments, B. Am. Meteorol. Soc., 93, 347-370, doi:10.1175/BAMS-D-11-00027.1, 2012.

Holloway, T., Levy II, H., and Kasibhatla, P.: Global distribution of carbon monoxide, J. Geophys. Res., 105, 12123-12147, 2000.

Illingworth, S. M., Remedios, J. J., Boesch, H., Moore, D. P., Sembhi, H., Dudhia, A., and Walker, J. C.: ULIRS, an optimal estimation retrieval scheme for carbon monoxide using IASI spectral radiances: sensitivity analysis, error budget and simulations, Atmos. Meas. Tech., 4, 269-288, doi:10.5194/amt-4-269-2011, 2011.

Jacquinet-Husson, N., Crepeau, L., Armante, R., Boutammine, C., Chédin, A., Scott, N. A., Crevoisier, C., Capelle, V., Boone, C., Poulet-Crovisier, N., Barbe, A., Campargue, A., Chris Benner, D., Benilan, Y., Bézard, B., Boudon, V., Brown, L. R., Coudert, L. H., Coustenis, A., Dana, V., Devi, V. M., Fally, S., Fayt, A., Flaud, J.-M., Goldman, A., Herman, M., Harrio, G. J., Jacquemart, D., Jolly, A., Kleiner, I., Kleinböhl, A., Kwabia-Tchana, F., Lavrentieva, N., Lacome, N., Li-Hong, X., Lyulin, O. M., Mandin, J.-Y., Maki, A., Mikhailenko, S., Miller, C. E., Mishina, T., Moazzen-Ahmadi, N., Müller, H. S. P., Nikitin, A., Orphal, J., Perevalov, V., Perrin, A., Petkie, D. T., Predoi-Cross, A., Rinsland, C. P., Remedios, J. J., Rotger, M., Smith, M. A. H., Sung, K., Tashkun, S., Tennyson, J., Toth, R. A., Vandaele, A.-C., and Vander Auwera, J.: The 2009 edition of the GEISA spectroscopic database, J. Quant. Spectrosc. Ra., 112, 2395-2445, doi:10.1016/j.jqsrt.2011.06.004, 2011.

Kopacz, M., Jacob, D. J., Fisher, J. A., Logan, J. A., Zhang, L., Megretskaia, I. A., Yantosca, R. M., Singh, K., Henze, D. K., Burrows, J. P., Buchwitz, M., Khlystova, I., McMillan, W. W., Gille, J. C., Edwards, D. P., Eldering, A., Thouret, V., and Nedelec, P.: Global estimates of CO sources with high resolution by adjoint inversion of multiple satellite datasets (MOPITT, AIRS, SCIAMACHY, TES), Atmos. Chem. Phys., 10, 855-876, doi:10.5194/acp-10-855-2010, 2010.

Lai, S. C., Baker, A. K., Schuck T. J., Slemr, F., Brenninkmeijer, C. A. M., van Velthoven, P., Oram, D. E., Zahn, A., and Ziereis, H.: Characterization and source regions of 51 high-CO events observed during Civil Aircraft for the Regular Investigation of the Atmosphere Based on an Instrument Container (CARIBIC) flights between south China and the Philippines 2005-2008, J. Geophys. Res., 116, D20308, doi:10.1029/2011JD016375, 2011.

Lewis, S. L., Brando, P. M., Phillips, O. L., van der Heijden, G. M. F., and Nepstad, D.: The 2010 Amazon drought, Science, 331, p. 554, 2011.

Lobert, J. M. and Warnatz, J.: Emissions from the combustion process in vegetation, in: Fire in the environment: The ecological, atmospheric, and climatic importance of vegetation fires, edited by: Crutzen, P. J. and Goldammer, J. G., Wiley, Chichester, 1537, 1993.

McMillan, W. W., Barnet, C., Strow, L., Chahine, M. T., McCourt, M. L., Warner, J. X., Novelli, P. C., Korontzi, S., Maddy, E. S., and Datta, S.: Daily global maps of carbon monoxide from NASA's Atmospheric Infrared Sounder, Geophys. Res. Lett., 32, L11801, doi:10.1029/2004GL021821, 2005.

Machida, T. Matsueda, H., Sawa, Y., Nakagawa, Y., Hirotani, K., Kondo, N., Goto, K., Nakazawa, T., Ishikawa, K., and Ogawa, T.: Worldwide measurements of atmospheric $\mathrm{CO}_{2}$ and other trace gas species using commercial airlines, J. Atmos. Ocean. Tech., 25, 1744-1754, doi:10.1175/2008JTECHA1082.1, 2008. 
Matsueda, H., Inoue, H. Y., Ishii, M., and Tsutsumi, Y.: Large injection of carbon monoxide into the upper troposphere due to intense biomass burning in 1997, J. Geophys. Res., 104, 2686726879, 1999.

Matsueda, H., Taguchi, S., Inoue, H. Y., and Ishii, M.: A large impact of tropical biomass burning on $\mathrm{CO}$ and $\mathrm{CO}_{2}$ in the upper troposphere, Sci. China, 45, 116-125, 2002.

Nedelec, P., Cammas, J.-P., Thouret, V., Athier, G., Cousin, J.-M., Legrand, C., Abonnel, C., Lecoeur, F., Cayez, G., and Marizy, C.: An improved infrared carbon monoxide analyser for routine measurements aboard commercial Airbus aircraft: technical validation and first scientific results of the MOZAIC III programme, Atmos. Chem. Phys., 3, 1551-1564, doi:10.5194/acp-3-15512003, 2003.

Pierangelo, C., Chédin, A., Heilliette, S., Jacquinet-Husson, N., and Armante, R.: Dust altitude and infrared optical depth from AIRS, Atmos. Chem. Phys., 4, 1813-1822, doi:10.5194/acp-41813-2004, 2004.

Pommier, M., Law, K. S., Clerbaux, C., Turquety, S., Hurtmans, D., Hadji-Lazaro, J., Coheur, P.-F., Schlager, H., Ancellet, G., Paris, J.-D., Nédélec, P., Diskin, G. S., Podolske, J. R., Holloway, J. S., and Bernath, P.: IASI carbon monoxide validation over the Arctic during POLARCAT spring and summer campaigns, Atmos. Chem. Phys., 10, 10655-10678, doi:10.5194/acp-1010655-2010, 2010.

Reichle Jr., H. G., Anderson, B. E., Connors, V. S., Denkins, T. C., Forbes, D. A., Gormsen, B. B., Lagenfelds, R. L., Neil, D. O., Nolf, S. R., Novelli, P. C., Pougatchev, N. S., Roell, M. M., and Steele, L. P.: Space shuttle based global CO measurments during April and October 1994, MAPS instrument, data reduction, and data validation, J. Geophys. Res., 104, 21443-21454, 1999.

Rinsland, C. P., Luo, M., Logan, J. A., Beer, R., Worden, H., Rider, D., Osterman, G., Gunson, M., Eldering, A., Goldman, A., Shephard, M., Cough, S. A., Rodgers, C., Lamperl, M., and Chiou, L.: Nadir measurements of carbon monoxide distributions by Tropospheric Emission Spectrometer instrument onboard the Aura Spacecraft: Overview of analysis approach and examples of initial results, Geophys. Res. Lett., 33, L22806, doi:10.1029/2006GL027000, 2006.

Rinsland, C. P., Luo, M., Shephard, M., Clerbaux, C., Boone, C. D., Bernath, P. F., Chiou, L., and Coheur, P. F.: Tropospheric emission spectrometer (TES) and atmospheric chemistry experiment (ACE) measurements of tropospheric chemistry in tropical southeast Asia during a moderate El Nino in 2006, J. Quant. Spectrosc. Ra., 109, 1931-1942, doi:10.1016/j.jqsrt.2007.12.020, 2008.

Roberts, G., Wooster, M. J., and Lagoudakis, E.: Annual and diurnal african biomass burning temporal dynamics, Biogeosciences, 6 , 849-866, doi:10.5194/bg-6-849-2009, 2009.

Roy, D. P., Boschetti, L., Justice, C. O., and Ju, J.: The collection 5 MODIS burnt area product - Global evaluation by comparison with the MODIS active fire product, Remote Sens. Environ., 112, 3690-3707, 2008.
Scharffe, D., Slemr, F., Brenninkmeijer, C. A. M., and Zahn, A.: Carbon monoxide measurements onboard the CARIBIC passenger aircraft using UV resonance fluorescence, Atmos. Meas. Tech., 5, 1753-1760, doi:10.5194/amt-5-1753-2012, 2012.

Scott, N. A.: A direct method of computation of the transmission function of an inhomogeneous gaseous medium-I: Description of the method, J. Quant. Spectrosc. Ra., 14, 691-704, doi:10.1016/0022-4073(74)90116-2, 1974.

Scott, N. A. and Chédin, A.: A fast line-by-line method for atmospheric absorption computations: The Automatised Atmospheric Absorption Atlas, J. Appl. Meteorol., 20, 556-564, 1981.

Stamnes, K., Tsay, S.-C., Wiscombe, W., and Jayaweera, K.: Numerically sable algorithm for discrete ordinate-method radiative transfer in multiple scattering and emitting layered media, Appl. Optics, 27, 2502-2509, 1988.

Turquety, S., Clerbaux, C., Law, K., Coheur, P.-F., Cozic, A., Szopa, S., Hauglustaine, D. A., Hadji-Lazaro, J., Gloudemans, A. M S., Schrijver, H., Boone, C. D., Bernath, P. F., and Edwards, D. P.: $\mathrm{CO}$ emission and export from Asia: an analysis combining complementary satellite measurements (MOPITT, SCIAMACHY and ACE-FTS) with global modeling, Atmos. Chem. Phys., 8, 5187-5204, doi:10.5194/acp-8-5187-2008, 2008.

Turquety, S., Hurtmans, D., Hadji-Lazaro, J., Coheur, P.-F., Clerbaux, C., Josset, D., and Tsamalis, C.: Tracking the emission and transport of pollution from wildfires using the IASI CO retrievals: analysis of the summer 2007 Greek fires, Atmos. Chem. Phys., 9, 4897-4913, doi:10.5194/acp-9-4897-2009, 2009.

van der Werf, G. R., Randerson, J. T., Giglio, L., Collatz, G. J., Kasibhatla, P. S., and Arellano Jr., A. F.: Interannual variability in global biomass burning emissions from 1997 to 2004, Atmos. Chem. Phys., 6, 3423-3441, doi:10.5194/acp-6-3423-2006, 2006.

van der Werf, G. R., Randerson, J. T., Giglio, L., Collatz, G. J., Mu, M., Kasibhatla, P. S., Morton, D. C., DeFries, R. S., Jin, Y., and van Leeuwen, T. T.: Global fire emissions and the contribution of deforestation, savanna, forest, agricultural, and peat fires (19972009), Atmos. Chem. Phys., 10, 11707-11735, doi:10.5194/acp10-11707-2010, 2010.

WMO: Technical Report of Global Analysis Method for Major Greenhouse Gases by the World Data Center for Greenhouse Gases, GAW Report No. 184, WMO/TD - No. 1473, 2009.

Yurganov, N. L., McMillan, W. W., Dzhola, A. V., Grechko, E. I., Jones, N. B., and van der Werf, G. R.: Global AIRS and MOPITT CO measurements: Validation, comparison, and links to biomass burning variations and carbon cycle, J. Geophys. Res., 113, D09301, doi:10.1029/2007JD009229, 2008. 